\title{
Extracellular Calcium Modulates Persistent Sodium Current- Dependent Burst-Firing in Hippocampal Pyramidal Neurons
}

\author{
Hailing Su, Gil Alroy, Eilon D. Kirson, and Yoel Yaari \\ Department of Physiology, Institute of Medical Sciences, The Hebrew University-Hadassah Faculty of Medicine, \\ Jerusalem 91120, Israel
}

The generation of high-frequency spike bursts ("complex spikes"), either spontaneously or in response to depolarizing stimuli applied to the soma, is a notable feature in intracellular recordings from hippocampal CA1 pyramidal cells (PCs) in vivo. There is compelling evidence that the bursts are intrinsically generated by summation of large spike afterdepolarizations (ADPs). Using intracellular recordings in adult rat hippocampal slices, we show that intrinsic burst-firing in CA1 PCs is strongly dependent on the extracellular concentration of $\mathrm{Ca}^{2+}\left(\left[\mathrm{Ca}^{2+}\right]_{0}\right)$. Thus, lowering $\left[\mathrm{Ca}^{2+}\right]_{0}$ (by equimolar substitution with $\mathrm{Mn}^{2+}$ or $\mathrm{Mg}^{2+}$ ) induced intrinsic bursting in nonbursters, whereas raising $\left[\mathrm{Ca}^{2+}\right]_{0}$ suppressed intrinsic bursting in native bursters. The induction of intrinsic bursting by low $\left[\mathrm{Ca}^{2+}\right]_{0}$ was associated with enlargement of the spike ADP. Low $\left[\mathrm{Ca}^{2+}\right]_{0}$-induced intrinsic bursts and their underlying ADPs were suppressed by drugs that reduce the persistent $\mathrm{Na}^{+}$current $\left(I_{\mathrm{NaP}}\right)$, indicating that this current mediates the slow burst depolarization. Blocking $\mathrm{Ca}^{2+}$ activated $\mathrm{K}^{+}$currents with extracellular $\mathrm{Ni}^{2+}$ or intracellular chelation of $\mathrm{Ca}^{2+}$ did not induce intrinsic bursting. This and other evidence suggest that lowering $\left[\mathrm{Ca}^{2+}\right]_{0}$ may induce intrinsic bursting by augmenting $I_{\mathrm{NaP}}$. Because repetitive neuronal activity in the hippocampus is associated with marked decreases in $\left[\mathrm{Ca}^{2+}\right]_{0}$, the regulation of intrinsic bursting by extracellular $\mathrm{Ca}^{2+}$ may provide a mechanism for preferential recruitment of this firing mode during certain forms of hippocampal activation.

Key words: intrinsic bursting; calcium; persistent sodium current; pyramidal cell; hippocampus; phenytoin; gap junction; PKC; rat
The discharge of many hippocampal CA1 pyramidal cells (PCs) in vivo is a mixture of single spikes and high-frequency bursts of several spikes (Kandel and Spencer, 1961; Fujita, 1975; Nuñez et al., 1990). There is convincing evidence that the spike bursts (or "complex spikes") are generated intrinsically by slow, voltagegated membrane currents (Kandel and Spencer, 1961; Fujita, 1975; Nuñez et al., 1990; Kamondi et al., 1998). Such bursts are thought to play important roles in electrical signaling, in neuronal synchronization, and in the induction of long-term synaptic plasticity (for review, see Lisman, 1997).

In isolated hippocampal slices perfused with standard saline, only a small fraction $(\sim 20 \%)$ of CA1 PCs manifest an intrinsic tendency to burst-fire; most of these neurons are regular firing cells (Schwartzkroin, 1975; Masukawa et al., 1982; Jensen et al., 1994). The scarcity of intrinsic bursters in CA1 in vitro may reflect the fact that the firing pattern of an individual PC is not an invariable attribute. Rather, it is strongly modulated by the ionic composition of the extracellular fluid. Thus, modest increases in extracellular $\mathrm{pH}$ (Church and Baimbridge, 1991) or concentration of $\mathrm{K}^{+}\left(\left[\mathrm{K}^{+}\right]_{\mathrm{o}}\right)$ (Jensen et al., 1994), or modest decreases in extracellular osmolality (Azouz et al., 1997), can convert regular firing PCs to intrinsic bursters. Because these factors vary as a function of ongoing neuronal activity in the brain, it is possible that the intrinsic firing pattern of CA1 PCs in vivo may alternate

\footnotetext{
Received Aug. 1, 2000; revised March 26, 2001; accepted March 27, 2001.

This work was supported by the Bundesministerium für Bildung Wissenschaft (BMBF), the Israel Ministry of Science (MOS), and the Israel Science Foundation (ISF) administered by the Israel Academy of Sciences and Humanities. E.D.K. was supported by a fellowship from Teva Pharmaceuticals Inc.

Correspondence should be addressed to Dr. Yoel Yaari, Department of Physiology, Hebrew University School of Medicine, P.O. Box 12272, Jerusalem 91121, Israel. E-mail: yaari@md2.huji.ac.il.

Copyright (C) 2001 Society for Neuroscience $\quad 0270-6474 / 01 / 214173-10 \$ 15.00 / 0$
}

between nonbursting and bursting in different states of hippocampal activation.

The baseline concentration of free extracellular $\mathrm{Ca}^{2+}\left(\mathrm{Ca}^{2+}{ }_{\mathrm{o}}\right)$ is $1.2-1.5 \mathrm{~mm}$, but neuronal activity can cause $\mathrm{Ca}^{2+}$ o concentration $\left(\left[\mathrm{Ca}^{2+}\right]_{\mathrm{o}}\right)$ to decrease considerably (Heinemann et al., 1977). Therefore, it is important to establish how changes in $\left[\mathrm{Ca}^{2+}\right]_{\mathrm{o}}$ affect the firing pattern of hippocampal neurons. In a previous study we concluded that somatic bursting in CA1 PCs is neither driven by $\mathrm{Ca}^{2+}$ currents nor terminated by $\mathrm{Ca}^{2+}$-activated $\mathrm{K}^{+}$ currents (Azouz et al., 1996). However, we noted that lowering $\left[\mathrm{Ca}^{2+}\right]_{0}$ increases the propensity of these neurons to burst in response to depolarization. In this study we describe this effect of low $\left[\mathrm{Ca}^{2+}\right]_{\mathrm{o}}$ in more detail and examine three putative hypotheses regarding its underlying mechanism: (1) suppression of repolarizing $\mathrm{Ca}^{2+}$-activated $\mathrm{K}^{+}$currents, (2) upmodulation of persistent $\mathrm{Na}^{+}$current $\left(I_{\mathrm{NaP}}\right)$, and (3) increase in electrotonic coupling through gap junctions. Our data are consistent only with the second hypothesis.

A preliminary report of these findings has been published previously in a recent abstract ( $\mathrm{Su}$ et al., 1999).

\section{MATERIALS AND METHODS}

Slice preparation. All experimental protocols were approved by the Hebrew University Animal Care and Use Committee. Transverse hippocampal slices were prepared from adult Sabra rats $(150-200 \mathrm{gm})$. Animals were anesthetized with ether and decapitated with a guillotine. The brain was removed and immediately immersed in ice-cold, oxygenated $\left(95 \% \mathrm{O}_{2}, 5 \% \mathrm{CO}_{2}\right)$ dissection saline. The caudal two-thirds of one hemisphere (containing one hippocampus) were glued to the stage of a Vibratome (Campden Instruments). Transverse slices (400 $\mu \mathrm{m}$ thick) were cut from the region of the hemisphere containing the anterior hippocampus. The hippocampal portion was dissected out of each slice and transferred to an incubation chamber containing oxygenated saline at room temperature $\left(21-24^{\circ} \mathrm{C}\right)$. For experimental recordings, the slices were transferred to an interface slice chamber and perfused from below 
with oxygenated $\left(95 \% \mathrm{O}_{2}, 5 \% \mathrm{CO}_{2}\right)$ saline at $33.5^{\circ} \mathrm{C}$. The upper surface of the slices was exposed to the humidified gas mixture. The slices were allowed to recover at least $1 \mathrm{hr}$ before the experiment was started.

Solutions and drugs. The standard saline solution contained (in $\mathrm{mm}$ ): $\mathrm{NaCl} 124, \mathrm{KCl} 3.5, \mathrm{MgSO}_{4} 2, \mathrm{CaCl}_{2} 2, \mathrm{NaHCO}_{3} 26$, and D-glucose 10, $\mathrm{pH}$ 7.3. Low-Ca ${ }^{2+}$ salines were prepared by equimolar substitution of $\mathrm{CaCl}_{2}$ with $\mathrm{MnCl}_{2}$. In some experiments, where indicated, $\mathrm{CaCl}_{2}$ was replaced with $\mathrm{MgCl}_{2}$. High-Ca ${ }^{2+}$ saline was prepared by replacing $\mathrm{MgSO}_{4}$ with $\mathrm{CaCl}_{2}$.

All of the salines also contained the glutamate receptor antagonists 6-cyano-7-nitro-quinoxaline-2,3-dione (CNQX; $15 \mu \mathrm{M})$ and 2-amino-5phosphono-valeric acid $(50 \mu \mathrm{M})$ to block fast EPSPs and the $\mathrm{GABA}_{\mathrm{A}}$ receptor antagonist bicuculline methiodide $(10 \mu \mathrm{M})$ to block fast IPSPs.

Salts and drugs were purchased from Sigma (St. Louis, MO), with the exception of CNQX (RBI, Natick, MA) and doxyl-stearic acid (Aldrich, Milwaukee, WI). Phenytoin was dissolved in $1 \mathrm{~N} \mathrm{NaOH}$. The phorbol esters 4 $\beta$-phorbol 12,13-dibutyrate (PDB) and 4 $\alpha$-phorbol 12,13didecanoate (PDC) were dissolved in dimethyl sulfoxide (DMSO), and doxyl-stearic acid was dissolved in ethanol before it was added to the saline. Control salines contained equivalent concentrations of DMSO or ethanol (not $>0.1 \%$ ), which had no effects on the measured parameters.

Intracellular recordings. Current-clamp recordings from the somata of PCs in the CA1 pyramidal layer were made using sharp, $\mathrm{K}^{+}$-acetatefilled (4 M) glass microelectrodes $(60-90 \mathrm{M} \Omega$ ). In some experiments, where indicated, $200 \mathrm{~mm}$ BAPTA, or $2 \%$ biocytin, were included in the filling solution. An active bridge circuit in the amplifier (Axoclamp 2A, Axon Instruments) allowed simultaneous injection of current and measurement of membrane potential. The bridge balance was carefully monitored and adjusted before each measurement. Bipolar platinum electrodes $(50 \mu \mathrm{m})$ connected to a stimulator by an isolation unit were used for focal stimulation $(1-20 \mathrm{~V}, 50-70 \mu \mathrm{sec})$ of pyramidal axons in the alveus. Neurons were identified as PCs if they responded with short latency spikes to antidromic stimulation and manifested strong spike frequency adaptation during a sustained depolarization. The PCs accepted for this study had stable resting potentials of at least $-55 \mathrm{mV}$ and overshooting action potentials.

Cell staining. For assessing the incidence of gap junctions among CA1 PCs, some neurons were injected with biocytin. After the experiment, the slices were fixed overnight in $4 \%$ paraformaldehyde, cut into thin $(120 \mu \mathrm{m})$ sections, and incubated with avidin-biotin complex (Vectastain ABC elite kit, Vector Laboratories, Burlingame, CA). The stained cells were photographed at $200 \times$ magnification.

Data measurement and analysis. The intracellular signals were digitized and stored on a personal computer using a data acquisition system (TL-1, Axon Instruments). Off-line data analyses were performed using pCLAMP software (Axon Instruments).

To measure passive membrane properties, the PCs were injected with small $(0.1-0.5 \mathrm{nA}) 200 \mathrm{msec}$ negative current pulses. The input resistance was provided by the slope of the linear regression line fitted through the linear portion of the steady-state voltage versus current amplitude plot. The apparent membrane time constant $\left(\tau_{\mathrm{m}}\right)$ was taken as the slowest component $\left(\tau_{0}\right)$ of multiexponential function fitted to the charging curve produced by application of a small negative current step (from onset to steady state), as suggested by Rall (1977). The fast spike afterhyperpolarization (AHP) was measured as the potential attained at the end of fast spike repolarization. A measure for the size of the spike and subthreshold afterdepolarizations (ADPs) was provided by the area delimited by the ADP waveform and resting membrane potential. This measure was sensitive to both ADP amplitude and duration. Inward rectification was evaluated from the nonlinear voltage responses to slow (0.9 sec long) depolarizing current ramps. The membrane potential at which the membrane began to rectify was determined by extrapolating a line fitted to the linear portion of the voltage-current relation. The initial and mean firing rates during a burst were calculated from the first interspike interval and from the mean interspike interval, respectively.

Averaged data are expressed as mean $\pm \mathrm{SD}$. The significance of the differences between the measured spike parameters was evaluated using Student's paired $t$ test or Wilcoxon's paired-sample test with a significance level of 0.05 . Correlation between the firing pattern and the incidence of dye coupling of the PCs was tested with the Spearman rank order correlation.

Classification of PC firing patterns. In this study we defined a burst as a cluster of three or more closely spaced action potentials, riding on a distinct slow depolarizing envelope. As suggested previously (Jensen et al., 1994, 1996; Azouz et al., 1997), PCs were classified into three groups according to their response to long (150-200 msec) depolarizing current pulses of increasing intensity (in steps of $30-100 \mathrm{pA}$ ). The variant firing patterns observed in CA1 PCs perfused with nominally $\mathrm{Ca}^{2+}$-free saline are portrayed in Figure 1. Nonbursters generated accommodating trains of independent action potentials in response to all suprathreshold stimuli (Fig. 1A). High-threshold bursters (HTBs) generated burst-like responses only when subjected to strong suprathreshold stimuli (Fig. 1B), whereas low-threshold bursters (LTBs) fired in burst mode in response to threshold-straddling stimuli. To quantify the propensity to generate a burst, the latter heterogeneous group was further divided into three subgroups of increasing tendency for burst generation. Grade I LTBs fired only one spike in response to a brief (3-5 msec) depolarizing current pulse (Fig. 1C); grade II LTBs generated a burst also in response to a brief stimulus (Fig. $1 D$ ); and grade III LTBs also fired spontaneously in burst mode (Fig. 1E). It should be stressed that this classification of CA1 PCs into five different subgroups does not imply a fundamental difference in mechanisms and is used only for descriptive purposes.

\section{RESULTS \\ Effects of lowering $\left[\mathrm{Ca}^{2+}\right]_{0}$ on the firing patterns of CA1 PCs}

In standard saline, the proportion of intrinsically bursting CA1 PCs was small and the bursting threshold in these bursters was high, as described previously (Jensen et al., 1994). Of 136 neurons examined, $112(82 \%)$ were nonbursters and $24(17 \%)$ were bursters (of which 20 were HTBs and 4 grade I LTBs). Lowering $\left[\mathrm{Ca}^{2+}\right]_{\mathrm{o}}$ markedly increased the incidence of, and decreased the threshold for, intrinsic bursting in most PCs. In the representative experiment illustrated in Figure 2, changing from standard to 1.2 mM Ca ${ }^{2+}$ saline converted the nonbursting PC (Fig. $2 A$ ) into an HTB (Fig. $2 B$ ). Further reduction of $\left[\mathrm{Ca}^{2+}\right]_{\mathrm{o}}$ to $0.5 \mathrm{~mm}$ converted the PC into a grade I LTB (Fig. $2 C$ ). Finally, in nominally $\mathrm{Ca}^{2+}$-free saline the PC changed into a grade II LTB (Fig. 2D).

Similar concentration-dependent effects were seen in 15 of 20 PCs exposed to graded reductions in $\left[\mathrm{Ca}^{2+}\right]_{\mathrm{o}}$, although the final grade of bursting attained in $\mathrm{Ca}^{2+}$-free saline varied among the neurons. As summarized in Figure 3, lowering $\left[\mathrm{Ca}^{2+}\right]_{\mathrm{o}}$ from 2 to $1.2 \mathrm{~mm}$ converted 8 of 17 nonbursters to HTBs. Further reduction to $0.5 \mathrm{~mm}$ converted many of the HTBs to LTBs. Subsequent exposure to $\mathrm{Ca}^{2}$-free saline further augmented the bursting propensity of these LTBs. Spontaneous intrinsic bursters (grade III LTBs) were encountered only in nominally $\mathrm{Ca}^{2+}$-free saline in 5 of the 20 PCs $(25 \%)$ in this sample.

The waveform of intrinsic bursts in low $\left[\mathrm{Ca}^{2+}\right]_{\mathrm{o}}$ was similar to that of native intrinsic bursts (Jensen et al., 1994, 1996). The number of intraburst spikes varied between three and seven across different cells (averaging $3.5 \pm 1.1 ; n=40$ ) but was rather constant in any given cell. The initial and mean firing rates during a burst were $178.7 \pm 28.8$ and $134.7 \pm 28.2 \mathrm{~Hz}(n=40)$, respectively.

\section{Effects of lowering $\left[\mathrm{Ca}^{2+}\right]_{0}$ on the spike ADP}

Lowering $\left[\mathrm{Ca}^{2+}\right]_{0}$ did not significantly affect resting membrane potential, input resistance, or time constant, nor did it affect spike threshold or amplitude (Table 1). However, it strongly modulated the spike afterpotentials, namely the fast AHP and ADP, in most PCs. As illustrated in Figure $2 E$, lowering $\left[\mathrm{Ca}^{2+}\right]_{\mathrm{o}}$ reduced the fast AHP and augmented the size of the ADP in a concentrationdependent manner. On average, changing from standard to $\mathrm{Ca}^{2+}$ free saline reduced the fast AHP by $5.8 \pm 4.0 \mathrm{mV}$ and variably augmented the spike ADP by $63.2 \pm 54.8 \%(n=40)$ (Table 1$)$.

During the lowering of $\left[\mathrm{Ca}^{2+}\right]_{\mathrm{o}}$, the size of the spike ADP and the propensity to burst increased in parallel (Fig. 2). Accordingly, the final size of the spike ADP in $\mathrm{Ca}^{2+}$-free saline was significantly larger in bursters $(275.9 \pm 103.7 \mathrm{mV} \cdot \mathrm{msec} ; n=33)$ than 


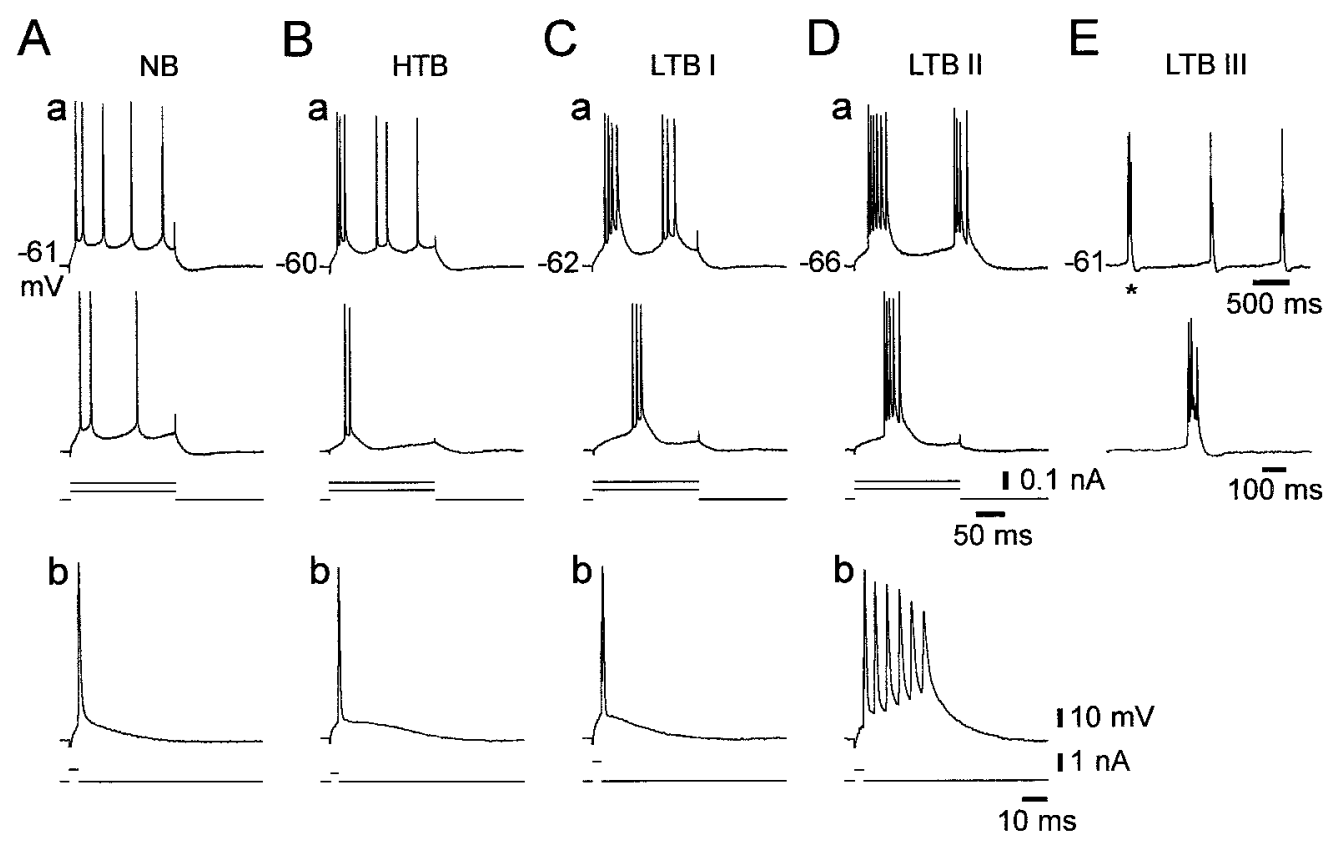

Figure 1. Variant firing patterns of CA1 PCs in low $\left[\mathrm{Ca}^{2+}\right]_{0}$. Intracellular recordings were made in five PCs in slices perfused with nominally Ca ${ }^{2+}$-free saline. The PCs were injected with long $(200 \mathrm{msec})$ and brief $(3-5 \mathrm{msec})$ positive current pulses of increasing intensity (in steps of 50-100 pA). The top panels $(a)$ in $A-D$ illustrate the firing patterns of four different PCs evoked by two long current pulses. The bottom panels $(b)$ depict the respective responses to brief stimuli. The injected current pulses are indicated below the voltage traces. $A$, A nonburster (NB). This neuron generated nonclustered spike trains in response to long current pulses $(a)$ and a single spike in response to brief current pulses $(b)$. $B$, A high-threshold burster $(H T B)$. This neuron generated an initial burst only in response to strong long current pulses $(a)$ and a single spike in response to brief current pulses $(b)$. $C$, Grade I low-threshold burster $(L T B I)$. This neuron generated bursts in response to threshold and suprathreshold long current pulses $(a)$, but a single spike in response to brief current pulses $(b)$. $D$, Grade II LTB (LTB II). This neuron fired bursts in response to both long $(a)$ and brief $(b)$ current pulses. $E$, Grade III LTB (LTB III). In addition to firing bursts in response to any threshold stimuli (data not shown), this neuron displayed spontaneous, rhythmic burst firing. The spontaneous burst marked with an asterisk in the top trace of $E$ is shown in the bottom trace on an expanded time scale. In this and the following Figures, dashed lines indicate truncated spikes. Resting potentials are provided to the left of topmost panels.

in nonbursters $(196.4 \pm 54.2 \mathrm{mV} \cdot \mathrm{msec} ; n=7)$. These observations are consistent with the notion that intrinsic bursts are triggered by suprathreshold spike ADPs (Kandel and Spencer, 1961; Jensen and Yaari, 1996).

\section{Effects of $I_{\mathrm{NaP}}$ blockers on low $\left[\mathrm{Ca}^{2+}\right]_{0}$-induced intrinsic bursting}

In pharmacologically untreated CA1 PCs, somatic intrinsic bursting is driven by $I_{\mathrm{NaP}}$ (Azouz et al., 1996). We examined whether a similar ionic mechanism underlies intrinsic bursting in low $\left[\mathrm{Ca}^{2+}\right]_{\mathrm{o}}$ by testing its sensitivity to three drugs previously shown to reduce $I_{\mathrm{NaP}}$ in $\mathrm{CA} 1 \mathrm{PCs}$, namely tetrodotoxin (TTX), the anti-epileptic drug phenytoin, and the protein kinase $\mathrm{C}$ (PKC) activator PDB. Representative results are shown in Figure 4.

\section{Tetrodotoxin}

This agent blocks both transient $\mathrm{Na}^{+}$current and $I_{\mathrm{NaP}}$ in CA1 PCs (French et al., 1990). As illustrated in Figure $4 A$, adding 0.1 $\mu \mathrm{M}$ TTX to the saline caused a progressive block of the burst responses concurrent with an increase in spike threshold. Longer exposures to TTX caused complete suppression of spike responses (data not shown). Similar results were consistently obtained in seven PCs.

\section{Phenytoin}

Phenytoin was shown to preferentially reduce $I_{\mathrm{NaP}}$ in CA1 PCs (Chao and Alzheimer, 1995; Segal and Douglas, 1997). We tested in nine PCs the effects of 50-100 $\mu \mathrm{M}$ phenytoin on low $\mathrm{Ca}^{2+}$ induced intrinsic bursting. In all cases, phenytoin reversibly suppressed intrinsic bursting, as illustrated in Figure $4 B$. Concur- rently, phenytoin caused a small $(3.36 \pm 3.26 \mathrm{mV})$ but significant increase in spike threshold (from $-54.0 \pm 2.6$ to $-50.8 \pm 2.9 \mathrm{mV}$; $n=9$ ) but did not significantly affect spike amplitude. Unlike TTX, phenytoin did not suppress the initiation of single spikes even after a prolonged ( $>1 \mathrm{hr})$ exposure.

\section{Phorbol esters}

In CA1 PCs, activation of PKC suppresses $I_{\mathrm{NaP}}$ (Alroy et al., 1999). Application of 2-10 $\mu \mathrm{M}$ PDB, a phorbol ester that potently activates PKC (Castagna et al., 1982), suppressed low $\mathrm{Ca}^{2+}$ induced intrinsic bursting within 30-45 min (Fig. 4C). The effect was irreversible with $1 \mathrm{hr}$ wash, but similar effects were seen in all nine bursters tested with this drug. Like phenytoin, PDB also caused a small $(\sim 4 \mathrm{mV})$ increase in spike threshold but did not significantly affect spike amplitude. To control for unspecific phorbol ester effects, we exposed slices for up to $1 \mathrm{hr}$ to $50 \mu \mathrm{M}$ PDC, a phorbol ester that does not activate PKC (Castagna et al., 1982). In all cases $(n=4)$, PDC did not affect intrinsic bursting (Fig. 4D).

\section{Effects of $I_{\mathrm{NaP}}$ blockers on low $\left[\mathrm{Ca}^{2+}\right]_{\mathrm{o}}$-enhanced spike ADPs}

In a fraction of the PCs, changing to $\mathrm{Ca}^{2+}$-free saline enhanced the spike ADP, but not sufficiently to trigger a burst in response to a brief stimulus (i.e., HTBs and grade I LTBs) (Fig. $1 B, C$ ). We tested in these neurons the effects of the three $I_{\mathrm{NaP}}$ blockers on the enhanced spike ADPs. As illustrated in Figure 5, the spike ADP was consistently suppressed by $0.1-0.2 \mu \mathrm{M}$ TTX (Fig. $5 A$ ) $(n=4), 50-100 \mu \mathrm{M}$ phenytoin (Fig. $5 B)(n=9)$, and $2-10 \mu \mathrm{M}$ PDB (Fig. $5 C)(n=9)$, but not by $50 \mu \mathrm{M}$ PDC $(n=3$; data not 

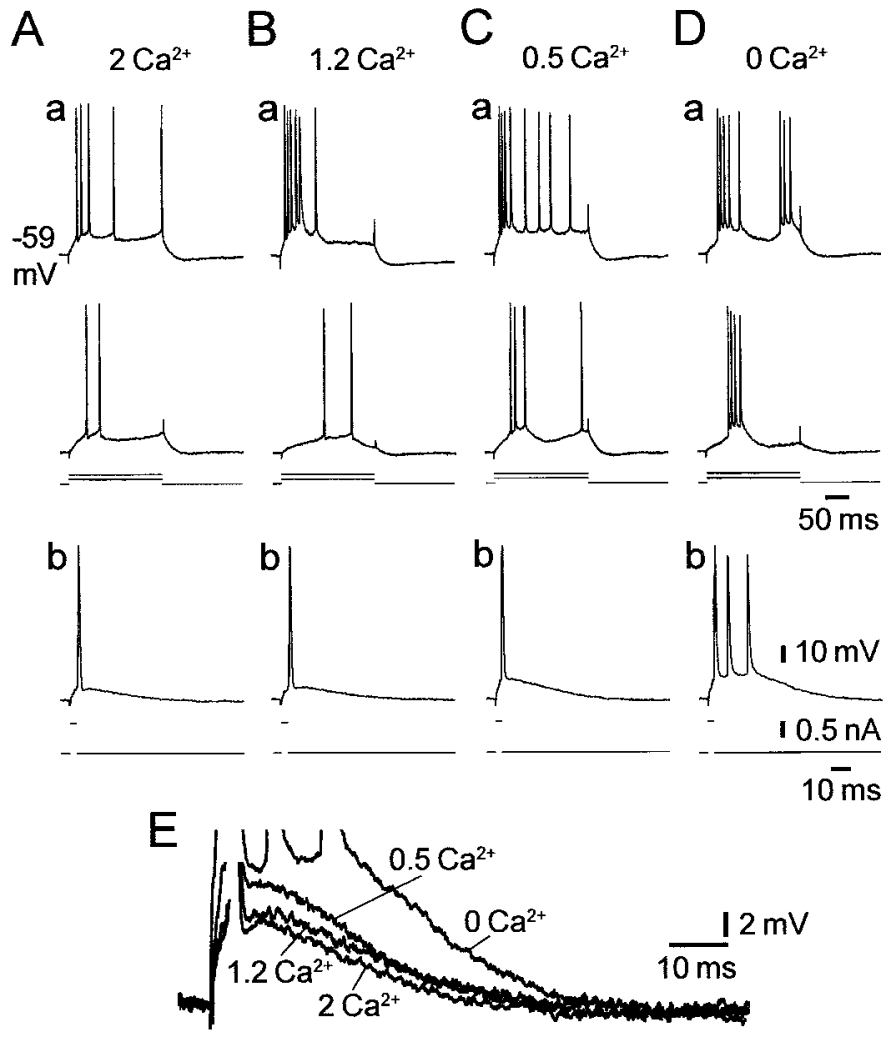

Figure 2. Effect of lowering $\left[\mathrm{Ca}^{2+}\right]_{\mathrm{o}}$ on the intrinsic firing pattern of a CA1 PC. Recordings were made in a slice perfused with salines containing different concentrations of $\mathrm{Ca}^{2+} . A$, In standard saline, the PC was a nonburster, as determined from its responses to $200 \mathrm{msec}(a)$ and $3 \mathrm{msec}$ (b) depolarizing current pulses. $B$, After a 30 min wash in $1.2 \mathrm{~mm}$ $\mathrm{Ca}^{2+}$-saline, the PC became an HTB, firing a burst in response to a strong $200 \mathrm{msec}$ depolarization $(a)$. C, After a $30 \mathrm{~min}$ wash in $0.5 \mathrm{mM} \mathrm{Ca}^{2+}$. saline, the PC became a grade I LTB, firing a burst also in response to a threshold $200 \mathrm{msec}$ depolarization $(a)$. $D$, Finally, after a $30 \mathrm{~min}$ wash in $\mathrm{Ca}^{2+}$-free saline, the PC became a grade II LTB, firing a burst in response to any threshold depolarization $(a, b)$. E , The transition from regular firing to bursting was associated with a progressive decrease in the fast AHP and an increase in size of the spike ADP, as shown in the overlay of the expanded traces from $b$ in $A-D$.

shown). These results are consistent with the notion that the enhanced spike ADPs in low $\left[\mathrm{Ca}^{2+}\right]_{0}$ are driven primarily by $I_{\mathrm{NaP}}$.

\section{Effects of $I_{\mathrm{NaP}}$ blockers on low $\left[\mathrm{Ca}^{2+}\right]_{\mathrm{o}}$-enhanced subthreshold ADPs}

When CA1 PCs are depolarized with a brief current pulse to near threshold potential, the membrane potential decays back to resting potential more slowly than expected from the membrane time constant. These subthreshold ADPs are readily blocked by TTX, but not by $\mathrm{Ca}^{2+}$ channel blockers (Azouz et al., 1996), suggesting that they are generated by $I_{\mathrm{NaP}}$, the activation threshold of which is slightly more negative than spike threshold (French et al., 1990). We tested the effects of lowering $\left[\mathrm{Ca}^{2+}\right]_{\mathrm{o}}$ on these potentials. In all cases $(n=22)$, as illustrated in Figure 6, deleting $\mathrm{Ca}^{2+}$ o markedly enhanced the subthreshold ADPs. Thus, the waveform of these potentials increased significantly from $134.9 \pm$ 50.3 to $333.5 \pm 71.2 \mathrm{mV} \cdot \mathrm{msec}$ after changing from standard to $\mathrm{Ca}^{2+}$-free saline. Consistent with the notion that they are generated by $I_{\mathrm{NaP}}$, these potentials were readily blocked by $0.1-0.2$ $\mu \mathrm{M}$ TTX (Fig. $6 A)(n=4), 50-100 \mu \mathrm{M}$ phenytoin (Fig. $6 B)(n=$ 9), and 2-10 $\mu \mathrm{M}$ PDB (Fig. $6 C)(n=9)$.

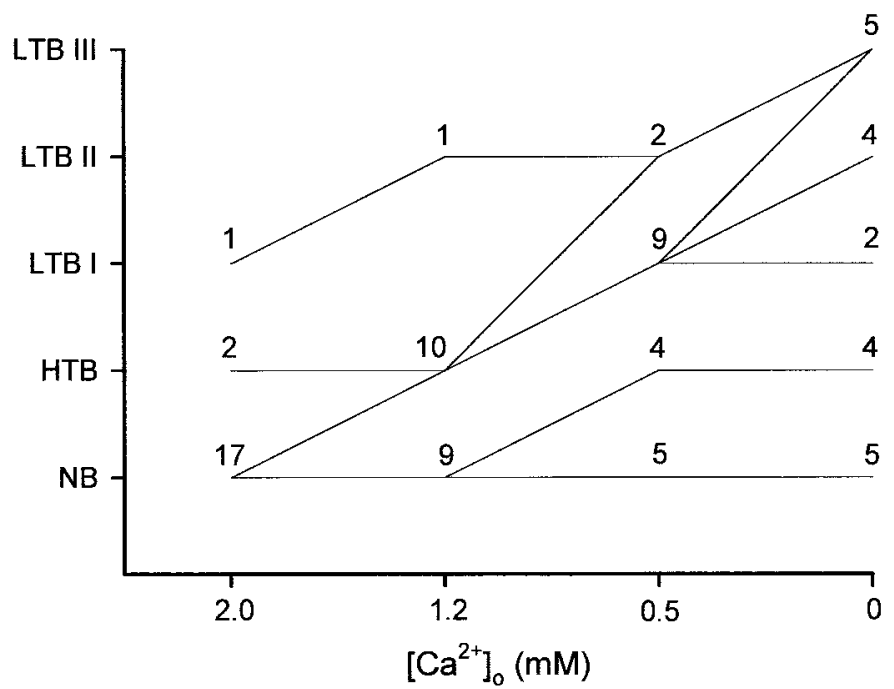

Figure 3. The firing patterns of CA1 PCs in different $\mathrm{Ca}^{2+}$ concentrations. The firing patterns of 20 CA1 PCs was monitored while $\left[\mathrm{Ca}^{2+}\right]_{\mathrm{o}}$ was reduced in a stepwise manner from $2 \mathrm{~mm}$ (standard saline) to $0 \mathrm{~mm}$ $\left(\mathrm{Ca}^{2+}\right.$-free saline). In control conditions, 17 PCs were nonbursters, 2 were HTBs, and only 1 was a grade I LTB. The lines in the graph depict the direction of change in firing pattern within each subclass of PCs when $\left[\mathrm{Ca}^{2+}\right]_{\mathrm{o}}$ is lowered to the next concentration. Thus, of the 17 native nonbursters, 8 PCs became HTBs in $1.2 \mathrm{mM} \mathrm{Ca}^{2+}$ and LTBs in $0.5 \mathrm{~mm}$ $\mathrm{Ca}^{2+}$, another 4 PCs became HTBs in $0.5 \mathrm{mM} \mathrm{Ca}^{2+}$, and the remaining 5 PCs did not change at all.

\section{Effects of $\mathrm{Ca}^{2+}$ current block with $\mathrm{Ni}^{2+}$}

The results described above established that low $\left[\mathrm{Ca}^{2+}\right]_{0}$-induced intrinsic bursting is most likely driven by $I_{\mathrm{NaP}}$. However, they did not indicate the mechanism by which lowering $\left[\mathrm{Ca}^{2+}\right]_{\mathrm{o}}$ augments the slow potentials that trigger the burst discharge. One possibility is that lowering $\left[\mathrm{Ca}^{2+}\right]_{\mathrm{o}}$ reduces outward $\mathrm{Ca}^{2+}$-activated $\mathrm{K}^{+}$ currents, thereby increasing the depolarizing impact of $I_{\mathrm{NaP}}$ (Azouz et al., 1996). Alternatively, lowering $\left[\mathrm{Ca}^{2+}\right]_{0}$ may upmodulate $I_{\mathrm{NaP}}$ itself. The first hypothesis predicts that blocking $\mathrm{Ca}^{2+}$ channels pharmacologically also would induce intrinsic bursting. We tested this notion in four nonbursters by adding 1 $\mathrm{mM} \mathrm{Ni}^{2+}$ (in replacement of $1 \mathrm{mM} \mathrm{Mg}^{2+}$ ) to the standard saline that perfused the slices. Consistent results were obtained in all cases and are illustrated in Figure 7. Adding $\mathrm{Ni}^{2+}$ suppressed the

Table 1. Effects of low $\left[\mathrm{Ca}^{2+}\right]_{0}$ on intrinsic membrane properties of CA1 PCs

\begin{tabular}{lrc} 
& \multicolumn{1}{c}{$2 \mathrm{Ca}^{2+}$} & \multicolumn{1}{c}{$0 \mathrm{Ca}^{2+}$} \\
\hline Resting $V_{\mathrm{M}}, \mathrm{mV}$ & $-64.3 \pm 3.8$ & $-64.6 \pm 3.8$ \\
$R_{\mathrm{N}}, \mathrm{M} \Omega$ & $28.4 \pm 9.1$ & $30.2 \pm 6.7$ \\
$\tau_{\mathrm{m}}, \mathrm{msec}$ & $13.7 \pm 5.2$ & $14.6 \pm 5.5$ \\
Spike threshold, $\mathrm{mV}$ & $-52.3 \pm 3.8$ & $-52.5 \pm 4.0$ \\
Spike amplitude, $\mathrm{mV}$ & $87.0 \pm 5.9$ & $87.5 \pm 6.6$ \\
Fast AHP, mV & $-56.0 \pm 4.8$ & $-50.1 \pm 5.0^{*}$ \\
ADP, $\mathrm{mV} \cdot \mathrm{msec}$ & $171.7 \pm 46.3$ & $261.5 \pm 117.1^{*}$
\end{tabular}

Recordings from each PC $(n=40)$ were made first in standard saline $\left(2 \mathrm{Ca}^{2+}\right)$ and then after $\sim 30 \mathrm{~min}$ of perfusion with nominally $\mathrm{Ca}^{2+}$-free saline $\left(0 \mathrm{Ca}^{2+}\right)$. All entries are expressed as mean $\pm \mathrm{SD}$. Resting $V_{\mathrm{M}}$ and $R_{\mathrm{N}}$ are resting membrane potential and input resistance, respectively. $\tau_{\mathrm{m}}$ is the passive time constant of the membrane measured at resting $V_{\mathrm{M}}$. Fast AHP is the membrane potential reached at the end of fast spike repolarization. ADP is the slow depolarizing potential that follows the fast AHP (see Materials and Methods). * Significantly different $(p<$ $0.05)$ from control. 
A $\mathrm{Ca}^{2+}$ $0 \mathrm{Ca}^{2+}, \mathrm{TTX}$

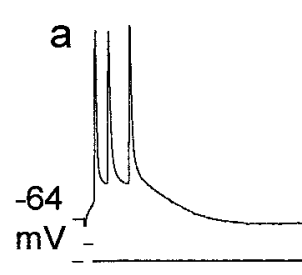

B $\quad \mathrm{Ca}^{2+}$
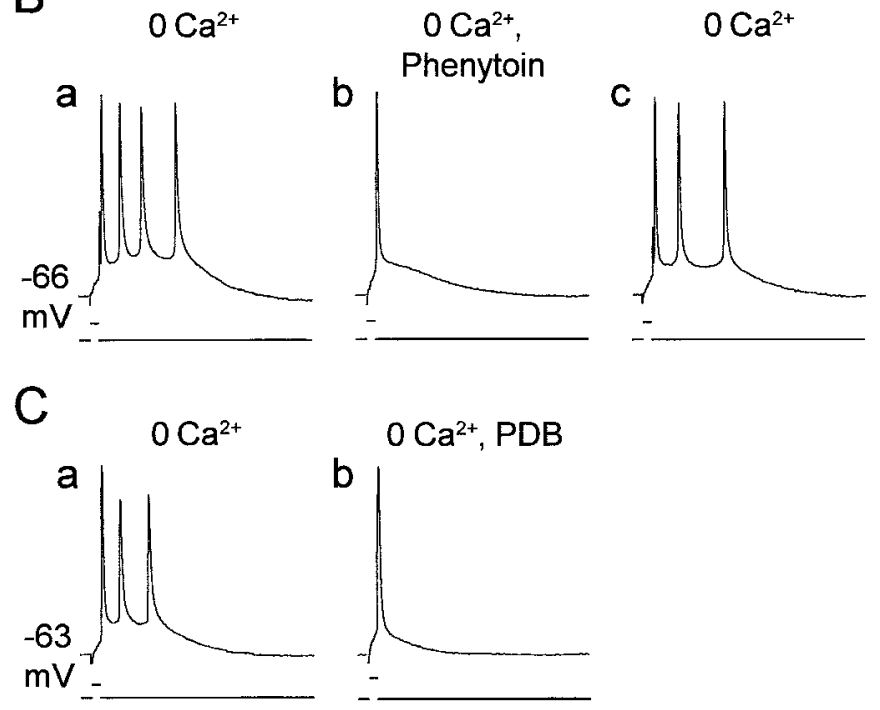

$0 \mathrm{Ca}^{2+}, \mathrm{PDB}$

b
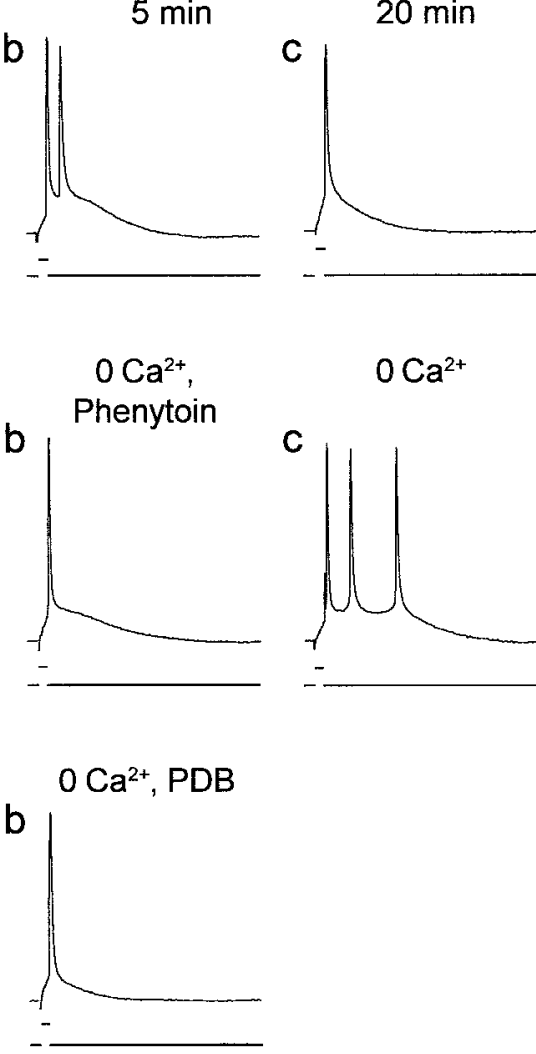

D

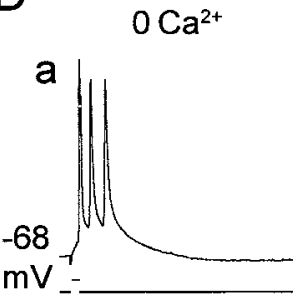

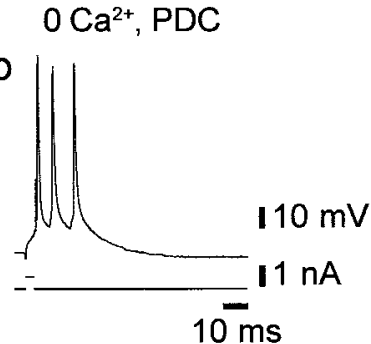

Figure 4. Blockers of $I_{\mathrm{NaP}}$ suppress intrinsic bursting in low $\left[\mathrm{Ca}^{2+}\right]_{\mathrm{o}}$. Recordings were made from four grade II LTBs in $\mathrm{Ca}^{2+}$-free saline. Burst firing was evoked by $3 \mathrm{msec}$ depolarizing stimuli. $A$, The responses of the neuron are shown before $(a)$ and 5 and $20 \mathrm{~min}$ after $(b$ and $c$, respectively) adding $0.1 \mu \mathrm{M}$ TTX to the $\mathrm{Ca}^{2+}$-free saline, which caused a gradual suppression of intrinsic bursting. $B$, The responses of the neuron are shown before $(a), 30 \mathrm{~min}$ after adding $50 \mu \mathrm{M}$ phenytoin to the $\mathrm{Ca}^{2+}$-free saline $(b)$, and $30 \mathrm{~min}$ after wash of phenytoin $(c) . C$, The responses of the neuron are shown before $(a)$ and $30 \mathrm{~min}$ after $(b)$ adding $5 \mu \mathrm{M}$ PDB to the $\mathrm{Ca}^{2+}$-free saline $(b)$. Both phenytoin and PDB blocked the burst response completely but affected the first spike very little. $D$, The responses of the neuron are shown before $(a)$ and 45 min after $(b)$ adding $50 \mu \mathrm{M}$ PDC to the $\mathrm{Ca}^{2+}$-free saline. No effect of this drug was noted.

fast AHP (Fig. 7, compare $a$ in $A$ and $B$ ), as expected from block of the fast $\mathrm{Ca}^{2+}$-activated $\mathrm{K}^{+}$current $\left(I_{\mathrm{c}}\right)$ (Storm, 1987). Likewise, it suppressed the slow AHP that follows a train of several spikes, which is generated by the slow $\mathrm{Ca}^{2+}$-activated $\mathrm{K}^{+}$current $\left(I_{\mathrm{AHP}}\right)$ (Madison and Nicoll, 1984), as well as the associated spike frequency accommodation (Fig. 7, compare $b$ in $A$ and $B$ ). Despite the apparent block of these $\mathrm{K}^{+}$currents, the nonbursting pattern of the PC did not change (Fig. 7, compare $c$ in $A$ and $B$ ).
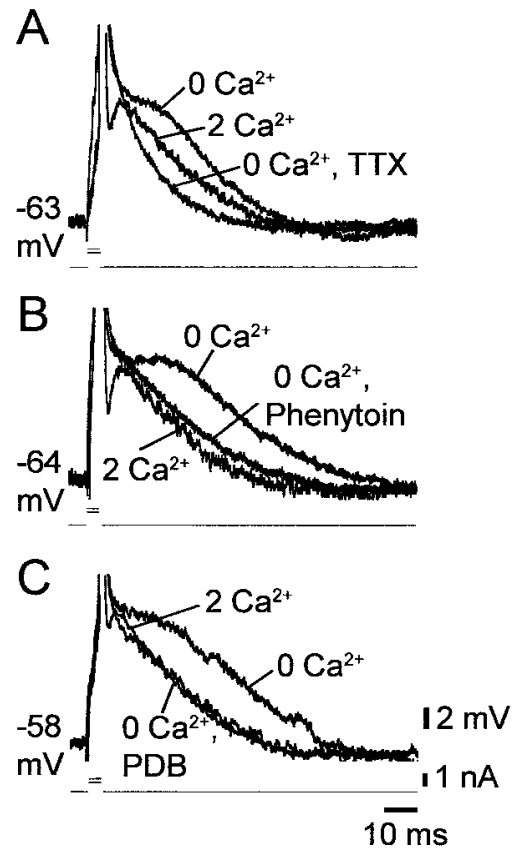

Figure 5. Blockers of $I_{\mathrm{NaP}}$ suppress spike ADPs in low $\left[\mathrm{Ca}^{2+}\right]_{\circ} \cdot A-C$, Recordings of single spikes evoked by $3 \mathrm{msec}$ stimuli were made in three CA1 PCs in slices perfused sequentially with standard saline $\left(2 \mathrm{Ca}^{2+}\right)$, $\mathrm{Ca}^{2+}$-free saline $\left(0 \mathrm{Ca}^{2+}\right)$, and $\mathrm{Ca}^{2+}$-free saline containing a drug known to suppress $I_{\mathrm{NaP}}$. In the three PCs the native spike was followed by an active ADP. Lowering $\left[\mathrm{Ca}^{2+}\right]_{\mathrm{o}}$ caused spike broadening, blocked the fast AHP, and enhanced the active ADP. The latter potential was completely depressed after $20 \mathrm{~min}$ exposure to $0.2 \mu \mathrm{M}$ TTX $(A)$. Likewise, it was markedly reduced after 30 min exposure to $50 \mu \mathrm{M}$ phenytoin $(B)$ or $5 \mu \mathrm{M}$ PDB $(C)$.

Yet, bursting was readily induced in the $\mathrm{Ni}^{2+}$-containing saline by deleting $\mathrm{Ca}^{2+}$ from the solution (Fig. $7 C, c$ ).

\section{Effects of buffering intracellular $\mathrm{Ca}^{2+}$ with BAPTA}

As an additional test for the role of $\mathrm{Ca}^{2+}$-activated currents in shaping the firing mode of CA1 PCs, we injected seven neurons with the $\mathrm{Ca}^{2+}$ chelator BAPTA by applying negative current pulses (up to $0.5 \mathrm{nA} ; 10-30 \mathrm{~min}$ ). The effects of BAPTA were similar in all cases. As illustrated in Figure 8, BAPTA injection expectedly suppressed the fast AHP (Fig. 8, compare $a$ in $A$ and $B)$, the slow AHP, and the associated spike frequency accommodation (Fig. 8, compare $b$ in $A$ and $B$ ). Despite these effects, BAPTA injection did not induce intrinsic bursting (Fig. 8, compare $c$ in $A$ and $B$ ). However, bursting was readily induced in the BAPTA-injected neuron by removing $\mathrm{Ca}^{2+}$ o (Fig. $8 C, c$ ).

\section{Effect of low $\left[\mathrm{Ca}^{2+}\right]_{0}$ on slow spikes}

Perfusing CA1 PCs with standard saline containing $10 \mathrm{~mm}$ TEA, which blocks various voltage-gated $\mathrm{K}^{+}$currents in these neurons (e.g., delayed rectifier and M-current) (Storm, 1990), induces compound slow (duration 100-400 msec) and fast spike responses to brief depolarizing stimuli. Deleting $\mathrm{Ca}^{2+}$ o converts the slow spikes to "plateau" potentials lasting 1-2 sec (García-Muñoz et al., 1993; Jensen et al., 1996). These potentials are blocked by TTX at low concentrations that do not affect the fast spikes, indicating that they are generated by $I_{\mathrm{NaP}}$. Accordingly, they are also blocked by phenytoin (H. Su and Y. Yaari, unpublished observations) and PKC activation (Alroy et al., 1999).

We tested whether blocking $\mathrm{Ca}^{2+}$-activated $\mathrm{K}^{+}$currents with $\mathrm{Ni}^{2+}$ also induces plateau potentials in TEA-containing saline. A 

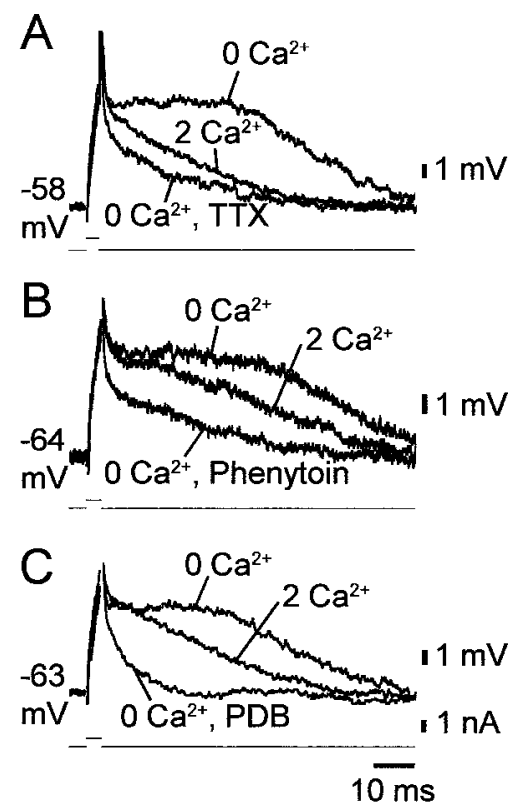

Figure 6. Blockers of $I_{\mathrm{NaP}}$ suppress subthreshold ADPs in low $\left[\mathrm{Ca}^{2+}\right]_{\text {。 }}$. $A-C$, Recordings of subthreshold ADPs evoked by 3 msec thresholdstraddling stimuli were made in three CA1 PCs in slices perfused sequentially with standard saline $\left(2 \mathrm{Ca}^{2+}\right), \mathrm{Ca}^{2+}$-free saline $\left(0 \mathrm{Ca}^{2+}\right)$, and $\mathrm{Ca}^{2+}$-free saline containing a drug known to suppress $I_{\mathrm{NaP}}$. In the three PCs, when the stimulus failed to trigger a spike, it evoked a slow depolarizing potential that declined more slowly to resting potential than expected from passive membrane charging. Lowering $\left[\mathrm{Ca}^{2+}\right]_{0}$ induced a subthreshold ADP in these PCs. The latter potential was suppressed by $0.2 \mu \mathrm{M}$ TTX $(20 \mathrm{~min} ; A), 50 \mu \mathrm{M}$ phenytoin $(30 \mathrm{~min} ; B)$, and 2 $\mu \mathrm{M}$ PDB (40 $\min ; C)$.

representative experiment is illustrated in Figure $9 A$. In standard saline containing $10 \mathrm{~mm}$ TEA, a brief depolarizing pulse evoked a complex of several fast spikes riding on a slow spike, followed by a slow AHP (Fig. 9A, a). Adding $1 \mathrm{mM} \mathrm{Ni}^{2+}$ abolished the slow AHP and slightly enhanced the slow spike, but did not induce a plateau potential (Fig. $9 A, b$ ). However, deleting $\mathrm{Ca}^{2+}$ from the $\mathrm{Ni}^{2+}$-containing saline induced a prolonged $(\sim 1.8 \mathrm{sec})$ plateau potential (Fig. $9 A, c$ ). This slow potential was blocked entirely by $0.2 \mu \mathrm{M}$ TTX before the primary fast spike was affected (Fig. $9 A$, d). Similar results were obtained in all experiments $(n=4)$.

These results indicated that blocking $\mathrm{Ca}^{2+}$-activated $\mathrm{K}^{+}$currents itself is not sufficient to induce plateau potentials in TEAcontaining saline. Rather, $\mathrm{Ca}^{2+}{ }_{\mathrm{o}}$ removal per se is required for this effect. Indeed, we found that even partial $\mathrm{Ca}^{2+}{ }_{o}$ replacement is effective in prolonging the slow spike component in TEAcontaining saline $(n=4)$. As illustrated in Figure $9 B$, reducing $\left[\mathrm{Ca}^{2+}\right]_{\mathrm{o}}$ in a stepwise manner caused a concentration-dependent growth of the plateau potential (Fig. 9B, $a-d$ ).

\section{Effect of low $\left[\mathrm{Ca}^{2+}\right]_{\text {o }}$ on inward rectification}

CA1 PCs display inward rectification, manifested as an apparent increase in input resistance near action-potential threshold (Hotson et al., 1979). A component of inward rectification persists after suppression of $\mathrm{Ca}^{2+}$ currents and is blocked by TTX, indicating that it is caused by activation of $I_{\mathrm{NaP}}$ (Benardo et al., 1982). If low $\left[\mathrm{Ca}^{2+}\right]_{\mathrm{o}}$ upmodulates $I_{\mathrm{NaP}}$, then it should augment TTX-sensitive inward rectification. We tested this notion in five slices perfused with saline containing $1 \mathrm{mM} \mathrm{Ni}^{2+}$ by injecting slow current ramps (duration $0.9 \mathrm{sec}$ ) of increasing magnitude into the PCs. In the example illustrated in Figure 10, the current was linearly increased from 0 to $160 \mathrm{pA}$, causing the neuron to depolarize from $-72 \mathrm{mV}$ to spike threshold potential (approximately $-60 \mathrm{mV}$ ). In standard saline containing $\mathrm{Ni}^{2+}$, inward rectification was seen at membrane potentials more positive than $-63.8 \mathrm{mV}$ (Fig. $10 A, a$ ). After changing to $\mathrm{Ni}^{2+}$-containing $\mathrm{Ca}^{2+}$-free saline, inward rectification occurred already at -67.1 $\mathrm{mV}$ (Fig. 10, trace b). Adding $1 \mu \mathrm{M}$ TTX completely blocked the inward rectification (Fig. 10, trace c). Similar results were obtained in all five experiments. On average, the membrane potential at which the membrane began to rectify shifted from $-62.0 \pm$ 2.9 to $-67.2 \pm 2.0 \mathrm{mV}$ after removal of $\mathrm{Ca}^{2+}$ o (a significant difference of $-5.2 \pm 1.4 \mathrm{mV})$.

\section{Effects of increasing $\left[\mathrm{Ca}^{2+}\right]_{0}$ on native intrinsic bursting and slow spikes}

In three experiments we tested how elevating $\left[\mathrm{Ca}^{2+}\right]_{\mathrm{o}}$ affects native intrinsic bursting. A representative experiment is illustrated in Figure $11 A$. In standard saline, strong positive current pulses evoked an initial burst response of three spikes (Fig. 11 $A$, a). Raising $\left[\mathrm{Ca}^{2+}\right]_{\mathrm{o}}$ to $4 \mathrm{~mm}$ (by substituting $2 \mathrm{mM} \mathrm{Mg}^{2+}$ with 2 $\mathrm{mm} \mathrm{Ca}{ }^{2+}$ ) blocked the burst response at all stimulation intensities (Fig. 11 $A, b$ ). This effect reversed after wash with standard saline (Fig. 11 $A, c$ ). Similar results were obtained in two additional PCs. The suppression of intrinsic bursting by doubling $\left[\mathrm{Ca}^{2+}\right]_{\mathrm{o}}$ was associated with a small $(\sim 3 \mathrm{mV})$ increase in spike threshold.

We also tested the effects of raising $\left[\mathrm{Ca}^{2+}\right]_{\mathrm{o}}$ on the slow spikes

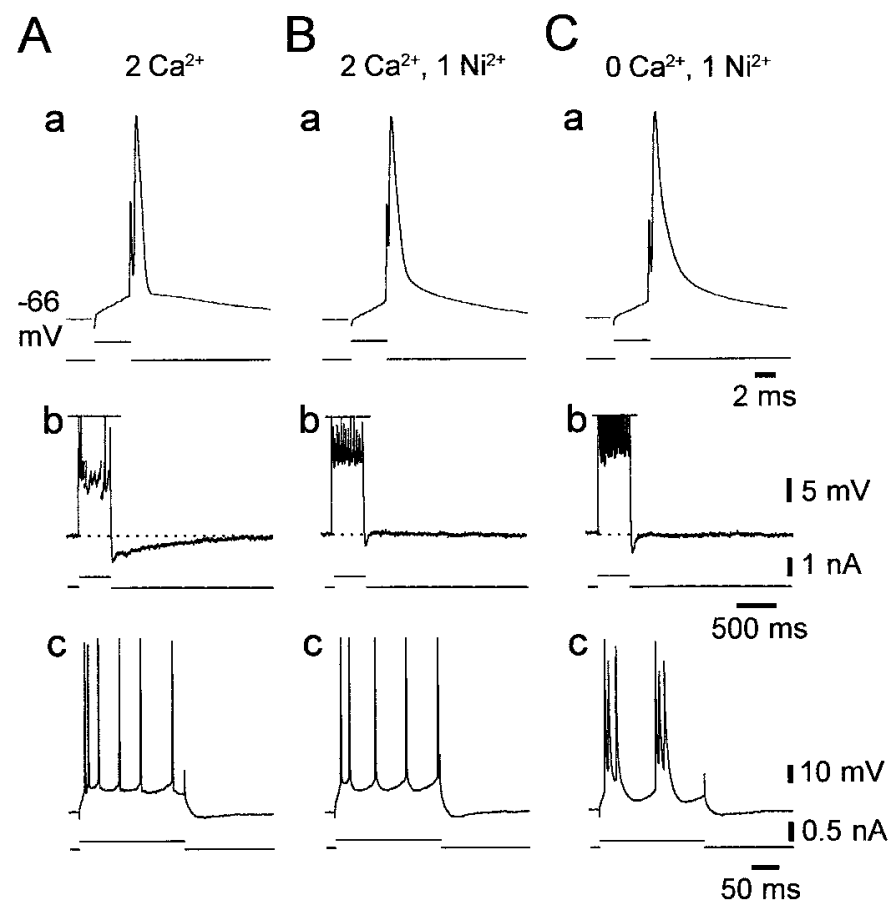

Figure 7. Block of $\mathrm{Ca}^{2+}$-activated $\mathrm{K}^{+}$currents with $\mathrm{Ni}^{2+}$ does not induce intrinsic bursting. Recordings were obtained from a native nonbursting CA1 PC. Shown are the responses of the neuron to $4 \mathrm{msec}(a)$, $400 \mathrm{msec}(b)$, and $200 \mathrm{msec}$ depolarizing stimuli $(c)$ in three conditions. $A$, In standard saline, the solitary spike was followed by distinct fast AHP and $\operatorname{ADP}(a)$, and repetitive firing was followed by a medium AHP and slow AHPs (b). B, After the change to standard saline containing $1 \mathrm{~mm}$ $\mathrm{Ni}^{2+}$, the fast and slow AHPs were suppressed, whereas the medium AHP was preserved $(a, b)$. Despite the reduction in spike frequency accommodation $(b)$, the nonbursting firing pattern of the PCs was unaltered $(c) . C$, Changing to $\mathrm{Ca}^{2+}$-free saline containing $1 \mathrm{mM} \mathrm{Ni}^{2+}(b)$ converted the PC to a grade I LTB $(c)$. 
in TEA-containing saline $(n=3)$. As shown in Figure $11 B$, raising $\left[\mathrm{Ca}^{2+}\right]_{0}$ to $4 \mathrm{~mm}$ selectively and reversibly blocked the slow spike component but spared the fast spike (Fig. 11B, $a-c$ ). Consequently, the slow AHP also was reversibly blocked by doubling $\left[\mathrm{Ca}^{2+}\right]_{\mathrm{o}}$. Similar results were obtained in all three experiments.

\section{Dye coupling and firing patterns of CA1 PCs in low $\left[\mathrm{Ca}^{2+}\right]$ 。}

Previous work in CA1 PCs suggested that bursters are more likely to be electrically coupled to each other via gap junctions than nonbursters (Church and Baimbridge, 1991). It was suggested that there may be a causal relationship between electrical coupling and intrinsic bursting. Presumably, the spread of spikes within a small network of electrically coupled neurons can generate a burst response in each neuron, which would appear as an "intrinsic" burst. Because lowering $\left[\mathrm{Ca}^{2+}\right]_{\mathrm{o}}$ reportedly increases gap junctional communication and, by implication, electrotonic coupling between CA1 PCs (Perez Velazquez et al., 1994), we examined whether this effect may contribute to low $\left[\mathrm{Ca}^{2+}\right]_{\mathrm{o}}-$ induced intrinsic bursting. To this end, we injected 46 PCs with the dye tracer biocytin during perfusion with nominally $\mathrm{Ca}^{2+}$. free saline. Of these, nine neurons $(21.4 \%)$ were found to be dye coupled to one, two, or three other PCs (mean number of PCs in a coupled cluster $2.6 \pm 0.9$ ). However, we found no significant correlation between the firing pattern of the neuron and the incidence of dye coupling (Table 2). Figure 12 illustrates two exemplary biocytin-injected neurons, a grade II LTB (Fig. 12A, $a$

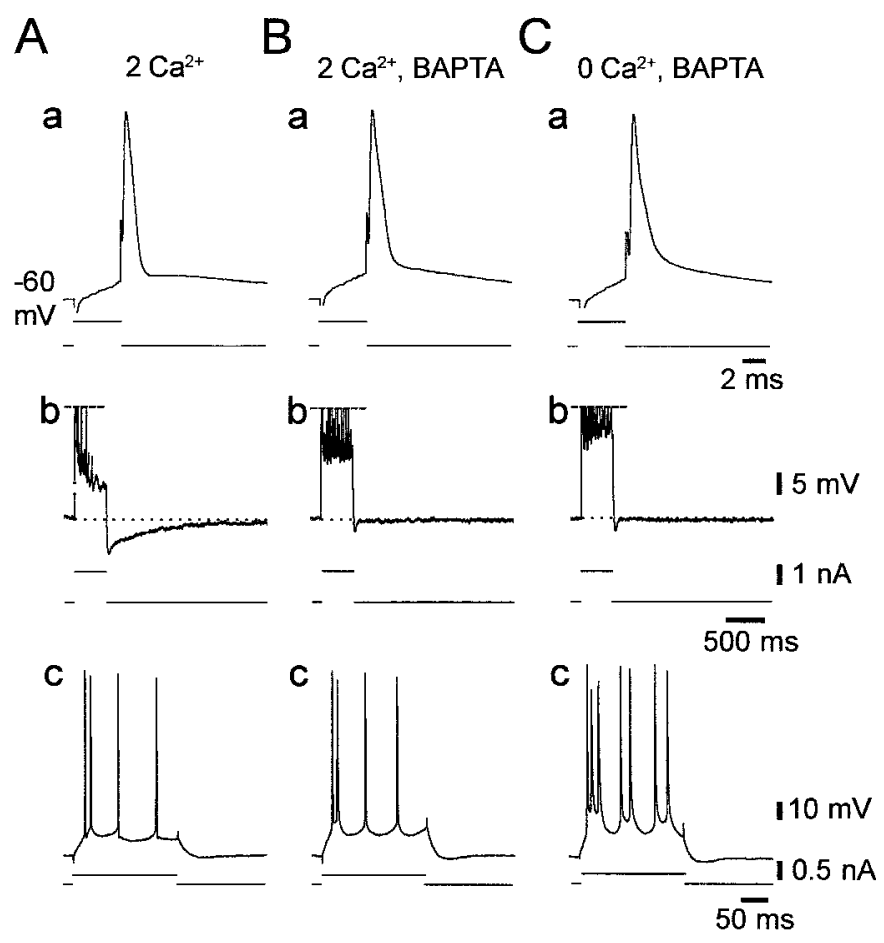

Figure 8. Buffering of intracellular $\mathrm{Ca}^{2+}$ concentration with BAPTA does not induce intrinsic bursting. Recordings were obtained from a native nonbursting CA1 PC. Shown are the responses of the neuron to 4 msec $(a), 400 \mathrm{msec}(b)$, and $200 \mathrm{msec}$ depolarizing stimuli $(c)$ in three conditions. $A$, In standard saline, the solitary spike was followed by distinct fast AHP and $\operatorname{ADP}(a)$, and repetitive firing was followed by a medium and slow AHPs $(b)$. $B$, Injecting BAPTA into the neuron suppressed the fast and slow AHPs and reduced spike frequency accommodation $(a, b)$, but the nonbursting firing pattern of the $\mathrm{PC}$ was unaltered $(c)$. $C$, Changing to $\mathrm{Ca}^{2+}$-free saline converted the PC to a grade I LTB (c).

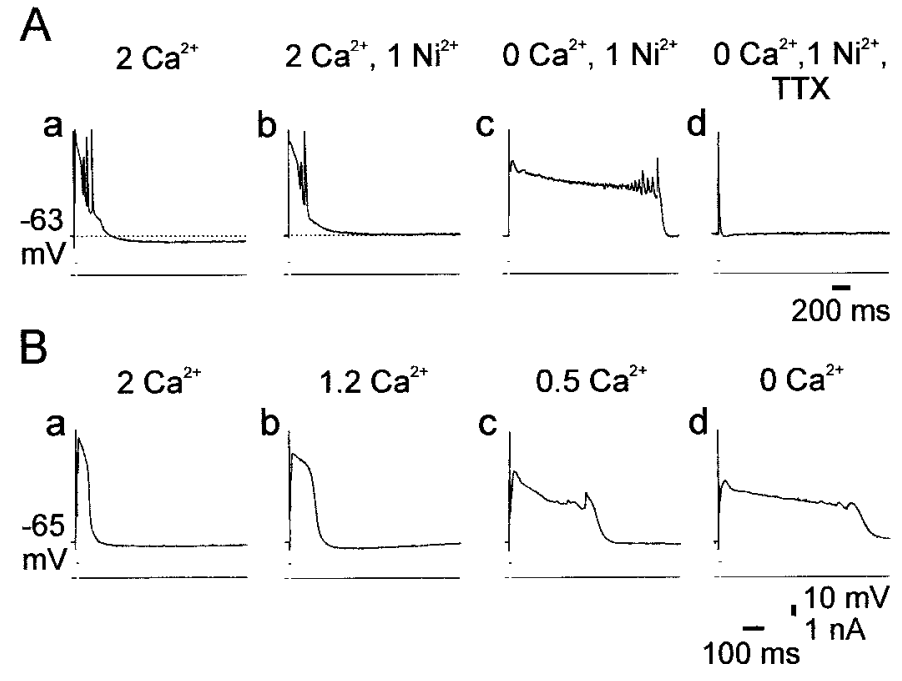

Figure 9. Lowering of $\left[\mathrm{Ca}^{2+}\right]_{\mathrm{o}}$, but not block of $\mathrm{Ca}^{2+}$-activated $\mathrm{K}^{+}$ currents, induces TTX-sensitive plateau potentials. $A$, In this experiment the slice was perfused with standard saline containing $10 \mathrm{~mm}$ TEA to block several voltage-gated $\mathrm{K}^{+}$currents. A constant negative current was injected into the cell to maintain the native resting membrane potential $(-63 \mathrm{mV})$. Suprathreshold responses were evoked by $5 \mathrm{msec}$ positive current pulses. Salines were exchanged every $30 \mathrm{~min}$. In standard saline containing TEA, the PC generated a compound response, consisting of fast spikes riding on a slow spike, and followed by a slow AHP $(a)$. Adding $1 \mathrm{mM} \mathrm{Ni}^{2+}$ to the saline suppressed the slow AHP completely and slightly prolonged the slow spike $(b)$. Deleting $\mathrm{Ca}^{2+}$ from the saline induced a prolonged plateau potential lasting $\sim 1.8 \mathrm{sec}(c)$, which was suppressed by $0.2 \mu \mathrm{M}$ TTX within $10 \mathrm{~min}$ of exposure $(d)$. $B$, In another slice perfused with salines containing $10 \mathrm{~mm}$ TEA, $\left[\mathrm{Ca}^{2+}\right]_{\mathrm{o}}$ was reduced in a stepwise manner every $30 \mathrm{~min}$. The responses of the PC to $5 \mathrm{msec}$ pulse stimulation are shown in standard saline $(a), 1.2 \mathrm{mM} \mathrm{Ca}^{2+}$ saline $(b), 0.5 \mathrm{mM} \mathrm{Ca}^{2+}$ saline $(c)$, and $\mathrm{Ca}^{2+}$-free saline $(d)$. The control response comprised fast and slow spikes $(a)$. The duration of the plateau potential increased as $\left[\mathrm{Ca}^{2+}\right]_{\mathrm{o}}$ decreased $(b-d)$.

and $b$ ), which was not coupled to other neurons (Fig. 12A,c), and a regular firing cell (Fig. 12B, $a$ and $b$ ), which was coupled to two other PCs (Fig. 12B, c).

It has been argued recently that in some neurons dye coupling may not be a reliable indicator for the presence of electrical coupling via gap junctions (Gibson et al., 1999). Therefore, we also tested the effect of the gap junctional blocker doxyl-stearic acid (Strata et al., 1997; Zahs and Newman, 1997) on low $\left[\mathrm{Ca}^{2+}\right]_{\mathrm{o}}$-induced intrinsic bursting. This drug was chosen because unlike other commonly used gap junction blockers tested (propionate, octanol, halothane, and carbenoxolone), it exerted no deleterious effects on intrinsic neuronal properties at concentrations that block neuronal gap junctions (Su and Yaari, unpublished observations). Addition of $50 \mu \mathrm{M}$ doxyl-stearic acid to the $\mathrm{Ca}^{2+}$-free saline did not affect intrinsic bursting during 45-60 min of perfusion in all cases ( $n=6$; data not shown).

Taken together, these data do not support a role for electrical coupling in the generation of intrinsic bursting in low $\left[\mathrm{Ca}^{2+}\right]_{\mathrm{o}}$.

\section{DISCUSSION}

The main finding in this study is that $\mathrm{Ca}^{2+}{ }_{\mathrm{o}}$ regulates the intrinsic firing mode of CA1 PCs. In standard saline containing $2 \mathrm{~mm}$ $\mathrm{Ca}^{2+}$, only a small fraction of these neurons burst-fire in response to somatic depolarization. Lowering $\left[\mathrm{Ca}^{2+}\right]_{\mathrm{o}}$ increases, whereas elevating $\left[\mathrm{Ca}^{2+}\right]_{0}$ decreases, the propensity of these neurons to generate bursts. We also show that intrinsic bursts induced by lowering $\left[\mathrm{Ca}^{2+}\right]_{\mathrm{o}}$ are driven by $I_{\mathrm{NaP}}$. The simplest hypothesis that 


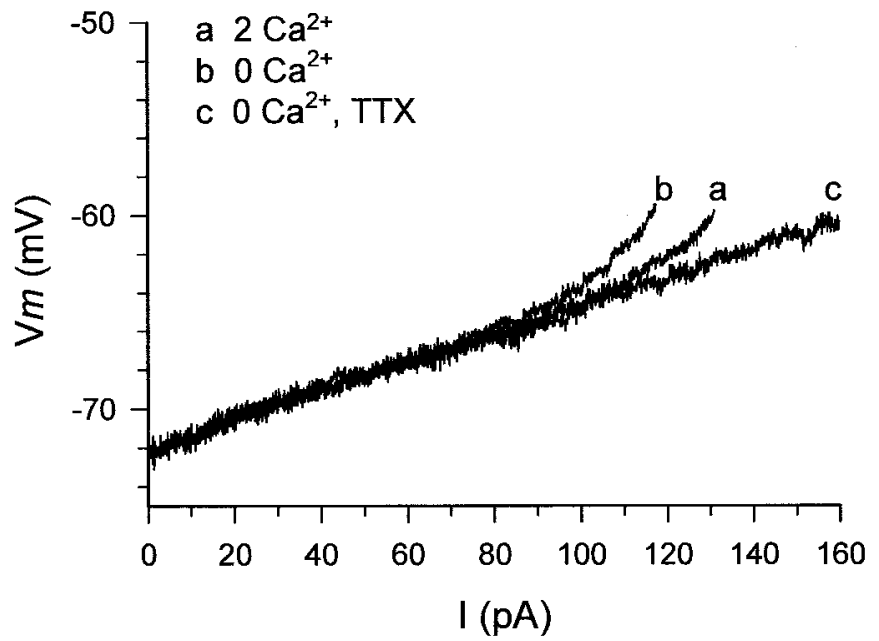

Figure 10. Lowering $\left[\mathrm{Ca}^{2+}\right]_{\mathrm{o}}$ enhances TTX-sensitive inward rectification. Recordings were obtained from a native nonbursting CA1 PC. The neuron was injected with current ramps from 0 to $160 \mathrm{pA}$ (duration 0.9 sec). Plotted are the subthreshold voltage responses of the neuron to these ramps. Each trace is an average of four consecutive responses. The slice was first perfused with standard saline containing $1 \mathrm{mM} \mathrm{Ni}^{2+}$ to block voltage-sensitive $\mathrm{Ca}^{2+}$ currents. In these conditions (trace a), the membrane potential first depolarized linearly from its resting level $(-72 \mathrm{mV})$ until $-63.8 \mathrm{mV}$, after which it depolarized exponentially until spike threshold was attained (at $-60 \mathrm{mV}$ ). After $30 \mathrm{~min}$ of perfusion with $\mathrm{Ni}^{2+}$-containing $\mathrm{Ca}^{2+}$-free saline (trace $b$ ), the nonlinear response began already at $-67.1 \mathrm{mV}$ and was steeper than in control. Addition of $0.1 \mu \mathrm{M}$ TTX (trace c) completely suppressed the nonlinear subthreshold response of the neuron in $10 \mathrm{~min}$.

accounts for our findings is that $\mathrm{Ca}^{2+}$ acting extracellularly exerts a depressant effect on noninactivating $\mathrm{Na}^{+}$channels that generate $I_{\mathrm{NaP}}$. Accordingly, decreases in $\left[\mathrm{Ca}^{2+}\right]_{\mathrm{o}}$ enhance intrinsic bursting via increases in $I_{\mathrm{NaP}}$.

\section{Ionic mechanism of intrinsic bursts in low $\left[\mathrm{Ca}^{2+}\right]_{0}$}

Several slow inward currents have been implicated in the generation of somatic bursts in cortical neurons, including voltagesensitive $\mathrm{Ca}^{2+}$ (Wong and Prince, 1981; Foehring and Waters, 1991; Deisz, 1996) and $\mathrm{Na}^{+}$currents (Franceschetti et al., 1995; Azouz et al., 1996; Mattia et al., 1997), and a $\mathrm{Ca}^{2+}$-activated cationic current (Kang et al., 1998). In CA1 PCs in vitro, native somatic bursting, as well as that induced by elevating $\left[\mathrm{K}^{+}\right]_{\mathrm{o}}$ (Jensen et al., 1994), are insensitive to block of $\mathrm{Ca}^{2+}$ currents. Rather, they are suppressed by blockers of $I_{\mathrm{NaP}}$, implicating the latter current in their generation (Azouz et al., 1996; Alroy et al., 1999). Somatic bursting can be induced in these neurons also by exposure to millimolar concentrations of 4-aminopyridine (4-AP), which blocks several $\mathrm{K}^{+}$conductances (Magee and Carruth, 1999). Unlike native bursting, 4-AP-induced bursts are suppressed by $\mathrm{Ca}^{2+}$ channel blockers, consistent with the view that they are generated by dendritic $\mathrm{Ca}^{2+}$ spikes (Magee and Carruth, 1999).

Two lines of evidence suggest that somatic bursting in low $\left[\mathrm{Ca}^{2+}\right]_{\mathrm{o}}$ is driven by $I_{\mathrm{NaP}}$. First, in most experiments bursting was readily induced in nominally $\mathrm{Ca}^{2+}$-free saline containing $2 \mathrm{~mm}$ $\mathrm{Mn}^{2+}$. Blocking $\mathrm{Ca}^{2+}$ channels with $\mathrm{Mn}^{2+}$ in addition to deleting $\mathrm{Ca}^{2+}$ ensured that neither $\mathrm{Ca}^{2+}$ currents nor $\mathrm{Na}^{+}$currents through $\mathrm{Ca}^{2+}$ channels (Lux et al., 1990) were involved in bursting. Thus, the only slow inward current available in this saline was $I_{\mathrm{NaP}}$. Second, intrinsic bursting induced by low $\left[\mathrm{Ca}^{2+}\right]_{\mathrm{o}}$ was readily suppressed by TTX, phenytoin, and PDB. Although these
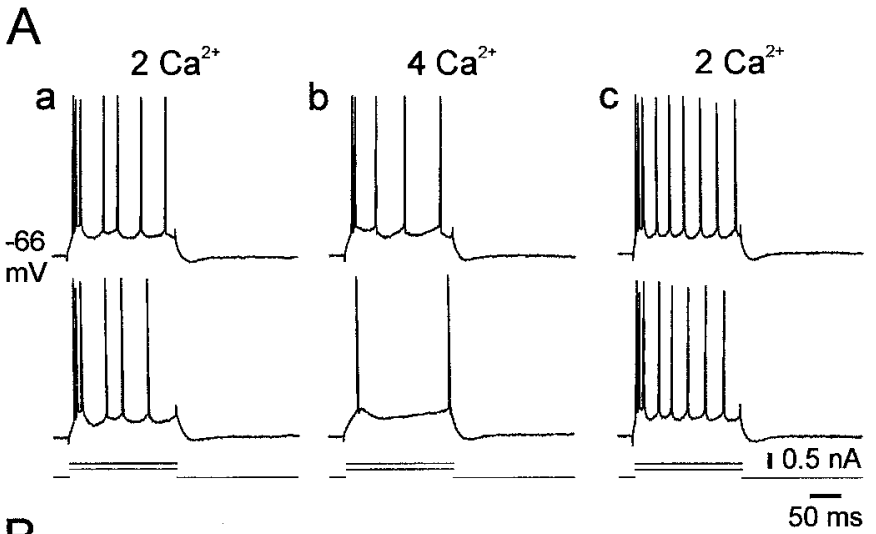

B
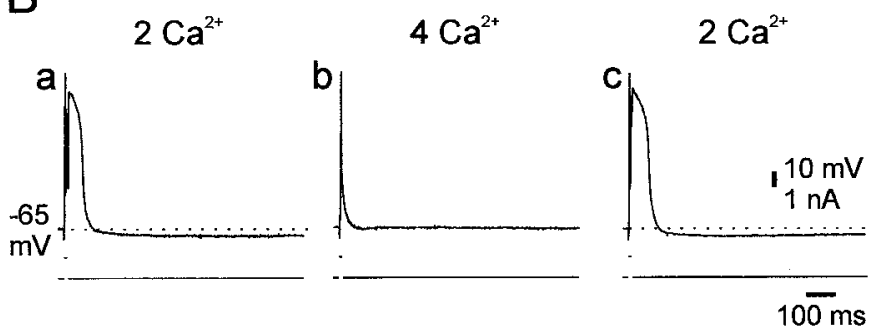

Figure 11. Raising $\left[\mathrm{Ca}^{2+}\right]_{\mathrm{o}}$ blocks native intrinsic bursting and slow spikes. $A$, In this experiment recordings were obtained from a native HTB. Shown are the responses of the neuron to $200 \mathrm{msec}$ depolarizing stimuli in standard saline $(a), 30$ min after switching to saline containing $4 \mathrm{mM} \mathrm{Ca}^{2+}(b)$, and 30 min after changing back to standard saline $(c)$. Raising $\left[\mathrm{Ca}^{2+}\right]_{\mathrm{o}}$ reversibly increased the threshold for evoking spikes and suppressed the initial burst response to the depolarizing pulses. $B$, In another slice perfused with salines containing $10 \mathrm{mM} \mathrm{TEA},\left[\mathrm{Ca}^{2+}\right]_{\mathrm{o}}$ was increased to $4 \mathrm{~mm}$. The responses of the $\mathrm{PC}$ to $5 \mathrm{msec}$ pulse stimulation are shown in standard saline $(a)$, after $20 \mathrm{~min}$ in $4 \mathrm{mM} \mathrm{Ca}^{2+}$ saline $(b)$, and after 30 min wash back to standard saline $(c)$. The slow spike was reversibly suppressed by doubling $\left[\mathrm{Ca}^{2+}\right]_{\mathrm{o}}(a-c)$.

drugs interact with voltage-gated $\mathrm{Na}^{+}$channels in different ways (Catterall, 1999), they share a common depressant effect on $I_{\mathrm{NaP}}$.

We have examined three hypotheses that explain why $I_{\mathrm{NaP}}$ becomes more effective in producing intrinsic bursting as $\left[\mathrm{Ca}^{2+}\right]_{\mathrm{o}}$ is lowered: (1) suppression of opposing $\mathrm{Ca}^{2+}$-activated $\mathrm{K}^{+}$currents, (2) upmodulation of $I_{\mathrm{NaP}}$ itself, and (3) increase in electrotonic coupling through gap junctions. These hypotheses will be assessed in the following sections.

\section{Suppression of $\mathbf{C a}^{2+}$-activated $\mathrm{K}^{+}$currents}

In CA1 PCs, $I_{\mathrm{C}}$ activates during the action potential and contributes largely to the late phase of spike repolarization (Storm,

Table 2. Relation between firing pattern and dye coupling in CA1 PCs perfused with $\mathrm{Ca}^{2+}$-free saline

\begin{tabular}{lcll} 
PC type & $n$ & $\begin{array}{l}\text { Number of } \\
\text { dye-coupled } \\
\text { clusters }\end{array}$ & $\begin{array}{l}\text { Incidence of dye } \\
\text { coupling }(\%)\end{array}$ \\
\hline NB & 10 & 2 & 20.0 \\
HTB & 10 & 3 & 30.0 \\
Grade I LTB & 9 & 2 & 22.2 \\
Grade II LTB & 8 & 2 & 25.0 \\
Grade III LTB & 9 & 1 & 11.1 \\
Total & 46 & 10 & 21.7
\end{tabular}

The biocytin-stained CA1 PCs $(n=46)$ were grouped according to their firing mode in nominally $\mathrm{Ca}^{2+}$-free saline. For each subset of PCs, the number of dye-coupled clusters observed and the overall incidence of dye coupling are provided. NB, Nonburster; HTB, high-threshold burster; LTB, low-threshold burster. 


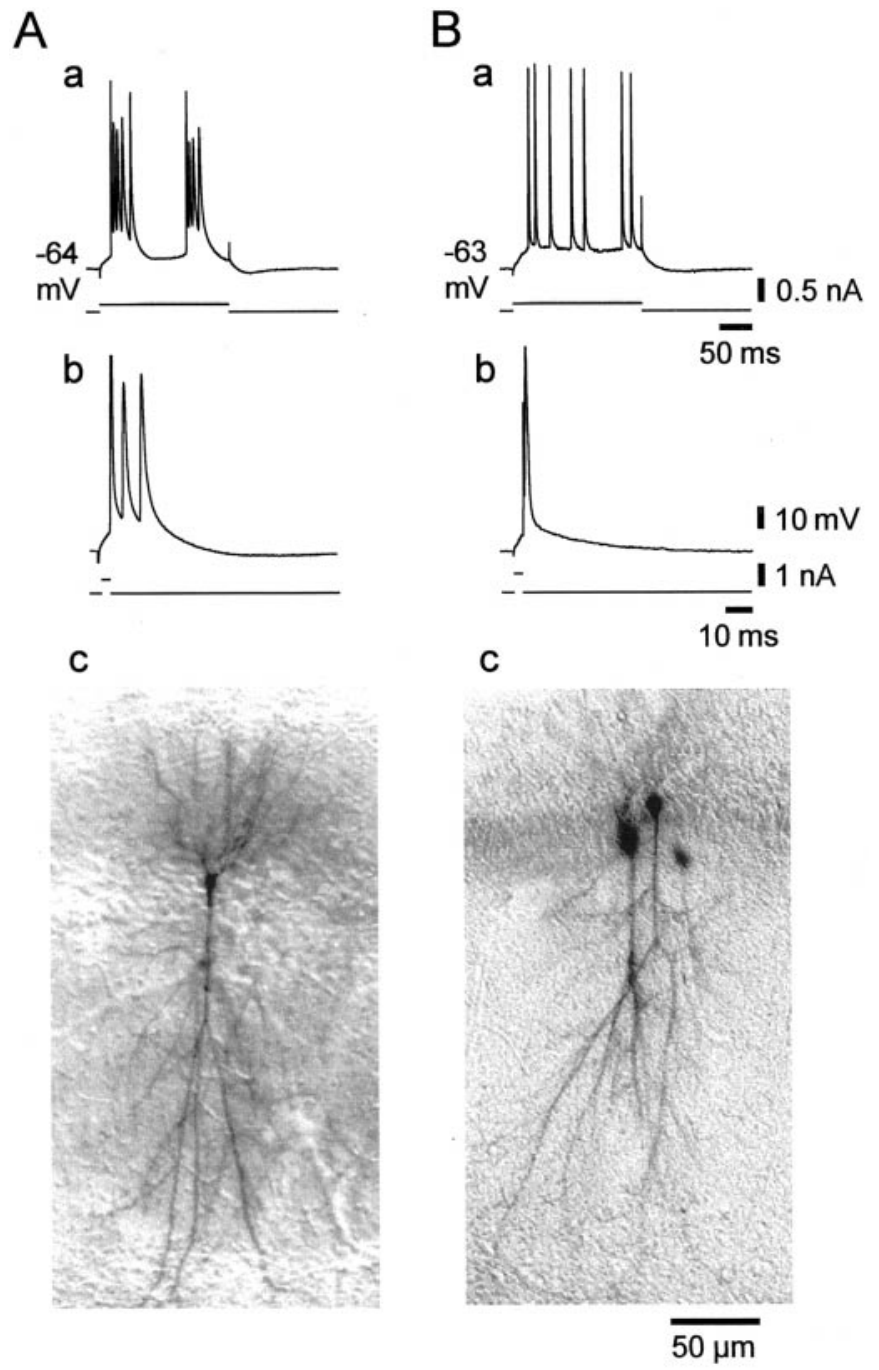

Figure 12. Dissociation between dye coupling and intrinsic bursting in low $\left[\mathrm{Ca}^{2+}\right]_{\mathrm{o}} . A, B$, Recordings from two native nonbursters $30 \mathrm{~min}$ after changing to $\mathrm{Ca}^{2+}$-free saline. Both PCs were stained with biocytin to detect dye coupling. $A$, This neuron became a grade II LTB in low $\left[\mathrm{Ca}^{2+}\right]_{\mathrm{o}}$, as is evident from its burst responses to $200 \mathrm{msec}(a)$ and $3 \mathrm{msec}$ depolarizing current pulses $(b)$. As shown in the photomicrograph of the neuron $(c)$, it was not dye coupled to other cells. $B$, This neuron remained nonbursting in low $\left[\mathrm{Ca}^{2+}\right]_{\mathrm{o}}(a, b)$. Biocytin injection into this cell resulted in the staining of three PCs $(c)$, suggesting that the neuron formed gap junctions with one or two other PCs.

1987). Thus, the density of $I_{C}$ influences the waveform of the spike ADP and may determine whether it will progress to a burst. We compared the effects of three experimental manipulations that cause $I_{\mathrm{C}}$ suppression, namely, lowering $\left[\mathrm{Ca}^{2+}\right]_{\mathrm{o}}$, blocking $\mathrm{Ca}^{2+}$ currents with extracellular $\mathrm{Ni}^{2+}$, and preventing intracellular $\mathrm{Ca}^{2+}$ accumulation with BAPTA. As expected, all of these manipulations reduced the $I_{\mathrm{C}}$-dependent fast AHP. However, only low $\left[\mathrm{Ca}^{2+}\right]_{0}$ induced intrinsic bursting, indicating that reduction in $I_{\mathrm{C}}$ (or any other $\mathrm{Ca}^{2+}$-activated current) by itself is not sufficient to invoke this firing pattern in CA1 PCs. Rather, lowering $\left[\mathrm{Ca}^{2+}\right]_{\mathrm{o}}$ exerts additional effects that are crucial for the induction of bursting.

\section{Upmodulation of $\boldsymbol{I}_{\mathrm{NaP}}$}

An attractive possibility is that low $\left[\mathrm{Ca}^{2+}\right]_{\mathrm{o}}$ upmodulates $\mathrm{I}_{\mathrm{NaP}}$. We tested this possibility by monitoring the effects of $\mathrm{Ca}^{2+}$ o removal on TTX-sensitive plateau potentials and inward rectification that are generated by $I_{\mathrm{NaP}}$. Both the plateau potentials and inward rectification were enhanced in this condition, supporting the view that lowering $\left[\mathrm{Ca}^{2+}\right]_{\mathrm{o}}$ upmodulates $I_{\mathrm{NaP}}$.

In a previous study in supraoptic hypothalamic neurons, lowering $\left[\mathrm{Ca}^{2+}\right]_{\mathrm{o}}$ enhanced $I_{\mathrm{NaP}}$ and the associated spontaneous intrinsic bursting (Li and Hatton, 1996). However, replacement of $\mathrm{Ca}^{2+}$ with other divalent cations prevented these effects, suggesting that they are caused by a net decrease in extracellular divalent ion concentration (which would shift $I_{\mathrm{NaP}}$ activation to more positive potentials by unscreening the external negative membrane surface potential) rather than by a specific decrease in $\left[\mathrm{Ca}^{2+}\right]_{0}$. In our experiments, the concentrations of divalent cations were maintained constant at $4 \mathrm{~mm}$ in all salines, and the induction of intrinsic bursting occurred regardless of the species of divalent cations used to replace $\mathrm{Ca}^{2+}{ }_{0}$. These data suggest that in CA1 PCs, $\mathrm{Ca}^{2+}$ o decreases $I_{\mathrm{NaP}}$ by a mechanism that involves its selective binding to membrane receptors. The receptors that bind $\mathrm{Ca}^{2+}{ }_{\mathrm{o}}$ may be the $\mathrm{Na}^{+}$channels themselves (Armstrong and Cota, 1991) or G-protein-coupled $\mathrm{Ca}^{2+}$-sensing receptors (Yamaguchi et al., 2000), such as metabotropic glutamate receptors (Kubo et al., 1998), that may modulate $I_{\mathrm{NaP}}$ via second messenger cascades. The latter mechanism is less likely, because $100 \mu \mathrm{M}$ neomycin $(n=3)$ and $10 \mathrm{~nm}$ gadolinium $(n=3)$, which activate $\mathrm{Ca}^{2+}$-sensing receptors (Xiong and MacDonald, 1999), failed to reverse the induction of intrinsic bursting by low $\left[\mathrm{Ca}^{2+}\right.$ ]o (Su and Yaari, unpublished observations).

\section{Increase in electrical coupling through gap junctions}

We also examined whether augmentation of electrotonic coupling via gap junctions contributes to the appearance of intrinsic bursting in low $\left[\mathrm{Ca}^{2+}\right]_{\mathrm{o}}$. Both experimental (Getting and Willows, 1974) and theoretical (Sherman and Rinzel, 1992) data suggest that electrotonic coupling can cause neurons to burst. Indeed, it was shown that raising extracellular $\mathrm{pH}$ enhances both dye coupling (and by implication, electrotonic coupling) and intrinsic bursting in CA1 PCs and that only PCs coupled to other neurons display bursting behavior (Church and Baimbridge, 1991). Although we found significant dye coupling between CA1 PCs bathed in low $\left[\mathrm{Ca}^{2+}\right]_{\mathrm{o}}$, we could not substantiate a role for electrotonic coupling in the bursting behavior. First, the incidence of dye coupling among bursters and nonbursters was the same. Second, the gap junction blocker doxyl-stearic acid did not affect intrinsic bursting. It should be noted that both the overall incidence of dye coupling $(21.4 \%)$ and the size of a coupled aggregate (two to four cells) in $\mathrm{Ca}^{2+}$-free saline were much lower than in high $\mathrm{pH}$ saline ( $88 \%$ and two to nine cells, respectively) (Church and Baimbridge, 1991). Thus, if electrical coupling via gap junctions and intrinsic bursting are causally associated, this mechanism may be more important for intrinsic bursting in high extracellular $\mathrm{pH}$ than in low $\left[\mathrm{Ca}^{2+}\right]_{\mathrm{o}}$.

\section{Functional implications}

Despite the strict homeostatic control of $\left[\mathrm{Ca}^{2+}\right]_{\mathrm{o}}$ in the brain, neuronal activity can cause substantial decreases in $\left[\mathrm{Ca}^{2+}\right]_{\mathrm{o}}(\mathrm{Hei}-$ nemann et al., 1977). In hippocampal slices perfused with $2 \mathrm{~mm}$ $\mathrm{Ca}^{2+}$ saline, repetitive orthodromic activation of CA1 PCs at $\theta$ frequencies $(5-10 \mathrm{~Hz})$ decreases $\left[\mathrm{Ca}^{2+}\right]_{0}$ down to $1.4 \mathrm{~mm}$ (Benninger et al., 1980). This decrease, in combination with an associated increase in $\left[\mathrm{K}^{+}\right]_{\mathrm{o}}$ (up to $12 \mathrm{~mm}$ ), would convert many nonbursting PCs into intrinsic bursters. This may explain why $\theta$ frequency orthodromic activation of CA1 PCs also leads to the development of postsynaptic bursting (Thomas et al., 1998). 
The induction of intrinsic bursting by activity-dependent decreases in $\left[\mathrm{Ca}^{2+}\right]_{\mathrm{o}}$ also may be germane to the genesis of epileptic seizures. In vivo recordings of $\left[\mathrm{Ca}^{2+}\right]_{\mathrm{o}}$ in experimental models of epilepsy have shown dramatic decreases in $\left[\mathrm{Ca}^{2+}\right]_{\mathrm{o}}$ (down to 0.2 $\mathrm{mm}$ ) during seizure activity (Pumain et al., 1985). These decreases would be expected to enhance intrinsic bursting, which in turn would contribute to the explosive development and spread of seizure activity (Jensen and Yaari, 1997). Consistent with this view is the finding that lowering $\left[\mathrm{Ca}^{2+}\right]_{\mathrm{o}}$ to $0.2 \mathrm{~mm}$ or less induces spontaneous population bursts in rat hippocampal slices despite the block of chemical synaptic transmission (Jefferys and Haas, 1982; Taylor and Dudek, 1982; Yaari et al., 1983).

\section{REFERENCES}

Alroy G, Su H, Yaari Y (1999) Protein kinase C mediates muscarinic block of intrinsic bursting in rat hippocampal neurons. J Physiol (Lond) 517:71-79.

Armstrong CM, Cota G (1991) Calcium ion as a cofactor in Na channel gating. Proc Natl Acad Sci USA 88:6528-6531.

Azouz R, Jensen MS, Yaari Y (1996) Ionic basis of spike afterdepolarization and burst generation in adult rat hippocampal CA1 pyramidal cells. J Physiol (Lond) 492:211-223.

Azouz R, Alroy G, Yaari Y (1997) Modulation of endogenous firing patterns by osmolarity in rat hippocampal neurones. J Physiol (Lond) 502:175-177.

Benardo LS, Masukawa LM, Prince DA (1982) Electrophysiology of isolated hippocampal pyramidal dendrites. J Neurosci 2:1614-1622.

Benninger C, Kadis J, Prince DA (1980) Extracellular calcium and potassium changes in hippocampal slices. Brain Res 177:165-172.

Castagna M, Takai Y, Kaibuchi K, Sano K, Kikkawa U, Nishizuka Y (1982) Direct activation of calcium-activated, phospholipid-dependent protein kinase by tumor-promoting phorbol esters. J Biol Chem 257:7847-7851.

Catterall WA (1999) Molecular properties of brain sodium channels: an important target for anticonvulsant drugs. Adv Neurol 79:441-456.

Chao TI, Alzheimer C (1995) Effects of phenytoin on the persistent $\mathrm{Na}^{+}$current of mammalian CNS neurones. NeuroReport 6:1778-1780.

Church J, Baimbridge KG (1991) Exposure to high-pH medium increases the incidence and extent of dye coupling between rat hippocampal CA1 pyramidal neurons in vitro. J Neurosci 11:3289-3295.

Deisz RA (1996) A tetrodotoxin-insensitive sodium current initiates burst firing of neocortical neurons. Neuroscience 70:341-351.

Foehring RC, Waters RS (1991) Contributions of low-threshold calcium current and anomalous rectifier (Ih) to slow depolarizations underlying burst firing in human neocortical neurons in vitro. Neurosci Lett 124:17-21.

Franceschetti S, Guatteo E, Panzica F, Sancini G, Wanke E, Avanzini G (1995) Ionic mechanisms underlying burst firing in pyramidal neurons: intracellular study in rat sensorimotor cortex. Brain Res 696:127-139.

French CR, Sah P, Buckett KJ, Gage PW (1990) A voltage-dependent persistent sodium current in mammalian hippocampal neurons. J Gen Physiol 95:1139-1157.

Fujita Y (1975) Two types of depolarizing after-potentials in hippocampal pyramidal cells of rabbits. Brain Res 94:435-446.

García-Muñoz A, Barrio LC, Buño W (1993) Membrane potential oscillations in CA1 hippocampal pyramidal neurons in vitro: intrinsic rhythms and fluctuations entrained by sinusoidal injected current. Exp Brain Res 97:325-333.

Getting PA, Willows AOD (1974) Modifications of neuron properties by electrotonic synapses. II. Burst formation by electrotonic synapses. J Neurophysiol 37:858-868.

Gibson JR, Beierlein M, Connors BW (1999) Two networks of electrically coupled inhibitory neurons in neocortex. Science 402:75-79.

Heinemann U, Lux HD, Gutnick MJ (1977) Extracellular free calcium and potassium during paroxysmal activity in the cerebral cortex of the cat. Exp Brain Res 27:237-243.

Hotson JR, Prince DA, Schwartzkroin PA (1979) Anomalous inward rectification in hippocampal neurons. J Neurophysiol 42:889-895.

Jefferys JGR, Haas HL (1982) Synchronized bursting of CA1 hippocampal pyramidal cells in the absence of synaptic transmission. Nature 300:448-450.

Jensen MS, Yaari Y (1997) Role of intrinsic burst firing, potassium accumulation, and electrical coupling in the elevated potassium model of hippocampal epilepsy. J Neurophysiol 77:1224-1233.

Jensen MS, Azouz R, Yaari Y (1994) Variant firing patterns in rat hippocampal pyramidal cells modulated by extracellular potassium. J Neurophysiol 71:831-839.

Jensen MS, Azouz R, Yaari Y (1996) Spike after-depolarization and burst generation in adult rat hippocampal CA1 pyramidal cells. J Physiol (Lond) 492:199-210.
Kamondi A, Acsady L, Buzsaki G (1998) Dendritic spikes are enhanced by cooperative network activity in the intact hippocampus. J Neurosci 18:3919-3928.

Kandel ER, Spencer WA (1961) Electrophysiology of hippocampal neurones: II. After-potentials and repetitive firing. J Neurophysiol 24:243-259.

Kang Y, Okada T, Ohmori H (1998) A phenytoin-sensitive cationic current participates in generating the afterdepolarization and burst afterdischarge in rat neocortical pyramidal cells. Eur $\mathrm{J}$ Neurosci 10:1363-1375.

Kubo Y, Miyashita T, Murata Y (1998) Structural basis for a $\mathrm{Ca}^{2+}$. sensing function of the metabotropic glutamate receptors. Science 279:1722-1725

Lux HD, Carbone E, Zucker $\mathrm{H}(1990) \mathrm{Na}^{+}$currents through lowvoltage-activated $\mathrm{Ca}^{2+}$ channels of chick sensory neurones: block by external $\mathrm{Ca}^{2+}$ and $\mathrm{Mg}^{2+}$. J Physiol (Lond) 430:159-188.

Li Z, Hatton GI (1996) Oscillatory bursting of phasically firing rat supraoptic neurones in low-Ca ${ }^{2+}$ medium: $\mathrm{Na}^{+}$influx, cytosolic $\mathrm{Ca}^{2+}$ and gap junctions. J Physiol (Lond) 496:379-394.

Lisman JE (1997) Bursts as a unit of neural information: making unreliable synapses reliable. Trends Neurosci 20:38-43.

Madison DV, Nicoll RA (1984) Control of the repetitive discharge of rat CA1 pyramidal neurones in vitro. J Physiol (Lond) 354:319-331.

Magee JC, Carruth M (1999) Dendritic voltage-gated ion channels regulate the action potential firing mode of hippocampal CA1 pyramidal neurons. J Neurophysiol 82:1795-1901.

Masukawa LM, Benardo LS, Prince DA (1982) Variations in electrophysiological properties of hippocampal neurons in different subfields. Brain Res 242:341-344.

Mattia D, Kawasaki H, Avoli M (1997) Repetitive firing and oscillatory activity of pyramidal-like bursting neurons in the rat subiculum. Exp Brain Res 114:507-517.

Nuñez A, Garcia-Austt E, Buño W (1990) Slow intrinsic spikes recorded in vivo in rat CA1-CA3 hippocampal pyramidal neurons. Exp Neurol 109:294-299.

Perez-Velazquez JL, Valiante TA, Carlen PL (1994) Modulation of gap junctional mechanisms during calcium-free induced field burst activity: a possible role for electronic coupling in epileptogenesis. J Neurosci 14:4308-4317

Pumain R, Menini C, Heinemann U, Louvel J, Silva Barrat C (1985) Chemical synaptic transmission is not necessary for epileptic seizures to persist in the baboon Papio papio. Exp Neurol 89:250-258.

Rall W (1977) Core conductor theory and cable properties of neurones. In: Handbook of physiology. The nervous system. Bethesda, MD: American Physiology Society.

Schwartzkroin PA (1975) Characteristics of CA1 neurons recorded intracellularly in the hippocampal in vitro slice preparation. Brain Res 85:423-436.

Segal MM, Douglas AF (1997) Late sodium channel openings underlying epileptiform activity are preferentially diminished by the anticonvulsant phenytoin. J Neurophysiol 77:3021-3304

Sherman A, Rinzel J (1992) Rhythmogenic effects of weak electrotonic coupling in neuronal models. Proc Natl Acad Sci USA 89:2471-2474.

Storm JF (1987) Action potential repolarization and a fast afterhyperpolarization in rat hippocampal pyramidal cells. J Physiol (Lond) 385:733-759.

Storm JF (1990) Potassium currents in hippocampal pyramidal cells. Prog Brain Res 83:161-187.

Strata F, Atzori M, Molnar M, Ugolini G, Tempia F, Cherubini E (1997) A pacemaker current in dye coupled hilar interneurons contributes to the generation of giant GABAergic potentials in developing hippocampus. J Neurosci 17:1435-1446.

Su H, Alroy G, Kirson ED, Yaari Y (1999) Intrinsic bursting induced by low extracellular calcium in rat hippocampal neurons: role of persistent sodium current. Neurosci Lett 54:S40.

Taylor CP, Dudek FE (1982) Synchronous neural afterdischarges in rat hippocampal slices without active chemical synapses. Science 217:810812 .

Thomas MJ, Watabe AM, Moody TD, Makhinson M, O'Dell TJ (1998) Postsynaptic complex spike bursting enables the induction of LTP by theta frequency synaptic stimulation. J Neurosci 17:7117-7126.

Wong RK, Prince DA (1981) Afterpotential generation in hippocampal pyramidal cells. J Neurophysiol 45:86-97.

Xiong ZG, MacDonald JF (1999) Sensing of extracellular calcium by neurones. Can J Physiol Pharmacol 77:715-721.

Yaari Y, Konnerth A, Heinemann U (1983) Spontaneous epileptiform activity of CA1 hippocampal neurons in low extracellular calcium solutions. Exp Brain Res 51:153-156.

Yamaguchi T, Chattopadhyay N, Brown EM (2000) G protein-coupled extracellular $\mathrm{Ca}^{2+}\left(\mathrm{Ca}^{2+}{ }_{\mathrm{o}}\right)$-sensing receptor $(\mathrm{CaR})$ : roles in cell signaling and control of diverse cellular functions. Adv Pharmacol 2000:209-253.

Zahs KR, Newman EA (1997) Asymmetric gap junctional coupling between glial cells in the rat retina. Glia 20:10-22. 